\title{
An Overview of Dissolved Fe and Mn Distributions During the 2010-2011 U.S. GEOTRACES North Atlantic Cruises: GEOTRACES GA03
}

\author{
Mariko Hatta ${ }^{1}$, Chris I Measures ${ }^{1}$, Jingfeng Wu${ }^{2}$, Saeed Roshan ${ }^{2}$, Jessica N. \\ Fitzsimmons $^{3}$, Peter Sedwick ${ }^{4}$, Pete Morton ${ }^{5}$. \\ 1School of Ocean and Earth Science and Technology, University of Hawai'i at Manoa, \\ 1000 Pope Road, Honolulu, HI 96822; mhatta@hawaii.edu; 1-808-956-6632; \\ chrism@soest.hawaii.edu; 1-808-956-8693
}
${ }^{2}$ Rosenstiel School for Marine and Atmospheric Sciences, University of Miami, 4600 Rickenbacker Causeway, Miami, FL 33149; 1-305-421-4714;
jwu@rsmas.miami.edu; sroshan@rsmas.miami.edu

${ }^{3}$ MIT/WHOI Joint Program in Chemical Oceanography, MIT E25-615, 45 Carleton St., Cambridge, MA 02142; 1-617-324-0283; jessfitz@mit.edu

4 Department of Ocean, Earth and Atmospheric Sciences, Old Dominion University, Norfolk, VA 23529; 757-683-4936; psedwick@odu.edu

${ }^{5}$ Department of Earth, Ocean and Atmospheric Science, Florida State University, Tallahassee, FL 32306; pmorton@fsu.edu 


\begin{abstract}
High-resolution dissolved $\mathrm{Fe}(\mathrm{dFe})$ and dissolved $\mathrm{Mn}(\mathrm{dMn})$ distributions were obtained using a trace metal clean rosette during the GEOTRACES GA03 zonal transect cruises (USGT10 \& USGT11) across the North Atlantic Ocean. This manuscript provides a general overview of the $\mathrm{dFe}$, as well as $\mathrm{dMn}$ and $\mathrm{dAl}$ distributions that reveal several Fe inputs at varying depths across the study region. Elevated $\mathrm{dFe}$ concentrations correlate with elevated dissolved Al concentrations in the surface waters of the subtropical gyre, indicating a significant atmospheric source of Fe, in contrast there is no apparent significant dust source for $\mathrm{Mn}$. In the subsurface waters, $\mathrm{dFe}$ maxima are a result of the remineralization process, as revealed by their correspondence with dissolved oxygen minima. Within the oxygen minimum, the ratio of $\mathrm{dFe}$ to apparent oxygen utilization (AOU) is lower than would be expected from the measured Fe content of surface water phytoplankton, suggesting that a significant amount of $\mathrm{dFe}$ that is remineralized at depth $(\sim 63-90 \%)$ is subsequently scavenged from the water column. The rate of remineralization, which is based on the slope of dFe:AOU plot, is similar across a wide area of the North Atlantic. In addition to the remineralization process, sedimentary inputs are apparent from elevated $\mathrm{dMn}$ signals in the eastern basin, particularly near the African coast. In the western basin, sedimentary input is also occurring along the advective flow path of the Upper Labrador Sea Water, as it transits along the North American continental shelf region. The largest dFe anomaly $(\sim 68 \mathrm{nM})$, which also corresponds to a dMn anomaly (up to $\sim 33 \mathrm{nM}$ ) is seen in the neutrally buoyant hydrothermal plume sampled over the Mid-Atlantic Ridge, and that signal is visible for $\sim 500 \mathrm{~km}$ to the west of the ridge.
\end{abstract}




\section{Introduction}

A primary goal of the international GEOTRACES program is to elucidate the fluxes and processes controlling the distributions of trace elements and their isotopes (TEIs) in the global ocean by mapping their distributions at the global scale (GEOTRACES, 2006, Science Plan, Scientific Committee on Oceanic Research, http://www.geotraces.org/science/science-plan). Iron (Fe), designated as a key parameter for the GEOTRACES program, is an essential micronutrient for phytoplankton, and regulates primary production in various regions of the oceans, particularly in the highnutrient low-chlorophyll (HNLC) ocean regions (Martin and Fitzwater, 1988; Martin et al., 1990). In addition, Fe supply to the surface ocean may regulate nitrogen fixation in some areas (Falkowski, 1997). Thus, defining the inputs, sinks and processes controlling the distribution of Fe in the oceans is a high priority of the GEOTRACES program.

During the last three decades, many water column profiles of dissolved $\mathrm{Fe}(\mathrm{dFe}$, here defined as the $<0.4 \mu \mathrm{m}$ or $<0.2 \mu \mathrm{m}$ size fraction) have been published, greatly increasing our knowledge of the marine geochemistry of this element, however there are still limited data along ocean sections crossing hydrographic boundaries (Klunder et al., 2011; Nishioka et al., 2013). The first 'oceanographically-consistent' vertical concentration profile of $\mathrm{dFe}$ in the northeast Pacific revealed a nutrient-like profile, with low concentrations in surface waters, gradually increasing to the oxygen minimum, and then decreasing slightly to $\sim 4,000 \mathrm{~m}$ depth (Landing and Bruland, 1987). These data were followed by additional observations in various ocean basins (Martin and Gordon, 1988; Martin et al., 1989; 1990; 1993), leading to a synthesis manuscript (Johnson et al., 1997), which suggested that $\mathrm{dFe}$ in oceanic deep water was relatively constant at $\sim 0.6$ $\mathrm{nmol} / \mathrm{L}$ and used a numerical model to make quantitative predictions of $\mathrm{dFe}$ in the deep water via iron oxide solubility and/or organic complexation of Fe. However, Boyle (1997) argued that Johnson et al. (1997) had overemphasized the constancy of deep water $\mathrm{dFe}$ concentrations, and suggested that surface inputs may play an important role in modifying the deep water $\mathrm{dFe}$ distribution over large areas. Further water column $\mathrm{dFe}$ data (Bruland et al., 1994; Boyle et al., 2005) revealed significant regional variability, indicative of multiple iron sources including vertical, lateral and recycled inputs. Also, this suggests that variations in the deep water residence times might also impact these 
concentrations (Bergquist and Boyle, 2006). Thus, exploring the regional variability of such processes is fundamentally important in gaining an understanding of the marine biogeochemistry of iron.

The international GEOTRACES program is designed to provide samples from all major world ocean basins, using validated 'trace-metal clean' sampling systems and intercalibrated analytical methods in order to produce a consistent and comparable global data set for trace elements such as iron. Additionally, by providing samples for which other trace elements and their isotopes with varying oceanographic behavior are determined, it will be possible to gain insights into processes that are not revealed by measurements of a single parameter.

The North Atlantic Ocean is an attractive region in which to examine the marine geochemistry of iron, because there are multiple sources of both new and recycled $\mathrm{dFe}$ that impact this ocean basin. The North Atlantic basin receives over $40 \%$ of the global mineral dust deposition to the ocean, mainly derived from Saharan and sub-Saharan North Africa (e.g., Duce et al., 1991; Husar et al., 1997; Mahowald et al., 2005), which constitutes a major source of iron to the surface ocean (Measures and Vink, 2000; Bergquist and Boyle, 2006; Croot et al., 2004; Measures et al., 2008). Also, there are coastal inputs from the surrounding continental shelves (Rijkenberg et al., 2012; Fitzsimmons et al., 2013), from the upwelling regime near the African coast that brings subsurface waters into the euphotic zone, and from hydrothermal activity along the MidAtlantic Ridge (German et al., 1991; Saito et al., 2013). In addition, high concentrations of $\mathrm{dFe}$ are associated with the oxygen minimum zone, reflecting recycled $\mathrm{dFe}$ input to the water column (Bergquist and Boyle, 2006). Furthermore, unlike the other ocean basins, the deep waters in the North Atlantic Ocean are rapidly advected, which reduces the overprinting of vertical cycling on the deep ocean.

Much of the variability in the oceanic distribution of iron may be related to the physical and chemical speciation of $\mathrm{dFe}$, thus an understanding of the various $\mathrm{dFe}$ species and their interconnections is also essential to understanding ocean Fe biogeochemistry. Further, since the biological availability of iron for phytoplankton growth is a major driving force in the geochemical cycling of this element, it is important to understand 
how the physical and chemical speciation of dFe (i.e., size fraction, redox state and organic complexation) influence the accessibility of this essential element for marine microorganisms. Thus, a comprehensive evaluation of all major dissolved Fe species is required to further our understanding of this element. In this paper, we summarize the main features of the distribution of $\mathrm{dFe}$ and $\mathrm{dMn}$ in the water column at the basin-scale, and use these data to identify the processes that are supplying iron and manganese to the North Atlantic Ocean. This work was carried out as part of the GEOTRACES GA03 zonal transects in the fall of 2010 and 2011. The different physicaochemical forms and isotopes of iron are dealt with elsewhere; Fe (II) distributions (Sedwick et al., in this issue.), soluble, colloidal Fe \& their Fe isotopic compositions (Fitzsimmons et al., in this issue.), Fe-binding ligands (Buck et al., in this issue), Fe isotopes (Conway and John., in press.), particulate Fe (Twining et al., in prep.), particulate Fe results from in situ pumping (Ohnemus and Lam., in this issue) and Fe in the oxygen minimum zone (Wu et al., in this issue).

\section{Methods}

\subsection{Sampling methods}

Water samples were collected at approximately two-degree intervals at 32 stations from the $R / V$ Knorr during the GEOTRACES GA03 expeditions, which took place October 15-November 4, 2010 (USGT2010: KN199-04: $7^{\circ} \mathrm{N}$ to $17^{\circ} \mathrm{N}$, mostly along $22^{\circ} \mathrm{W}$ ) and November 6-December 11, 2011 (USGT2011: KN204-01/02: $70^{\circ} \mathrm{W}$ to $25^{\circ} \mathrm{W}$ ) in the North Atlantic Ocean. Water column sampling stations are shown in Figure 1. The 2010 cruise (USGT10) started from Lisbon and sailed southward along $22^{\circ} \mathrm{W}$, and then from the Mauritanian coast to the Cape Verde islands (the Mauritanian transect, shown in Figure 1c). The 2011 cruise (USGT11) sailed from Woods Hole, MA, USA, following a repeat hydrographic section southeast of Cape Cod (Line W), then from Bermuda across to the Cape Verde islands.

Water column samples were obtained using the custom-built U.S. GEOTRACES trace-metal clean CTD rosette, consisting of a plastic-coated aluminum frame, titanium pressure housings for electronics and sensors, no sacrificial zinc anodes, and 24 x $12 \mathrm{~L}$ 
General Oceanics GO-FLO bottles modified for trace metal sampling (Cutter and Bruland, 2012). Before deployment and immediately upon recovery, the tops of the GOFLO bottles were covered with polyethylene shower-caps, and the bottles were removed from the frame and carried into the U.S. GEOTRACES clean container laboratory for sub-sampling. The GO-FLO bottles were pressurized to 10 psi using HEPA-filtered compressed air, and samples were filtered through $0.2 \mu \mathrm{m}$ Pall Acropak Supor filter capsules that had been pre-cleaned by soaking overnight and flushed with 5L of unacidified seawater. The $0.2 \mu \mathrm{m}$-filtered seawater samples were acidified to $\mathrm{pH} 2 \mathrm{using}$ trace metal-grade $\mathrm{HCl}$. All sub-sampling was undertaken in the clean container using rigorous trace-metal clean protocols (Cutter and Bruland, 2012). In addition, surfacewater ( $\sim 2 \mathrm{~m}$ depth) samples were collected using an underway towed-fish pumped seawater system (Johnson et al., 2007), and samples were sequentially filtered in-line at less than 8 psi through sequential $0.45 \mu \mathrm{m}$ Osmonics and $0.2 \mu \mathrm{m}$ Polycarbonate (PCTE) cartridge filters.

\subsection{Analytical methods}

Seawater samples were collected at both full-depth stations and demi stations (upper $1000 \mathrm{~m}$ ), with filtered subsamples drawn into acid pre-washed $125 \mathrm{ml}$ polymethylpentene bottles after three sample rinses; sample bottles were stored in polyethylene bags in the dark at room temperature before the determination, which was usually within 24 hours of collection. Prior to analysis, samples for dissolved aluminum $(\mathrm{dAl})$, iron $(\mathrm{dFe})$ and manganese $(\mathrm{dMn})$ were acidified by adding $125 \mu \mathrm{l}$ sub-boiling distilled $6 \mathrm{~N} \mathrm{HCl}$, and were then microwaved in groups of 4 for 3 minutes in a $900 \mathrm{~W}$ microwave oven to achieve a temperature of $60 \pm 10{ }^{\circ} \mathrm{C}$, in an effort to release dissolved Fe from complexation in the samples. Samples were allowed to cool for at least 1 hour prior to flow injection analysis.

\section{Flow Injection Analysis (FIA) method}

Dissolved Fe and Mn were determined in the filtered, acidified, microwavetreated subsamples using flow injection analysis (FIA) methods of Measures et al. (1995) for dFe and Resing and Mottl (1992) for dMn. Samples were analyzed in groups of 8, 
and the samples collected at each station were generally analyzed together during the same day. The detection limit and the precision of $\mathrm{dFe}$ determinations was approximately $0.064 \mathrm{nM}$ and $3.1 \%$ for the 2010 cruise, and $0.064 \mathrm{nM}$ and $2.8 \%$ for the 2011 cruise. The detection limit and the precision of dMn analyses was approximately $0.05 \mathrm{nM}$ and $2.9 \%$ for the 2011 cruise. There is no shipboard dMn data from the 2010 cruise as a result of FIA problems. Instead we use dMn data from inductively coupled plasma-mass spectrometry (ICP-MS) for the 2010 cruise. The ICPMS method had a detection limit of approximately $0.04 \mathrm{nM} \mathrm{dMn}$ and a precision of $6.6 \%$ for the 2010 cruise. Comparison between the shipboard FIA and shorebased ICPMS showed that the results from FIA were always higher than ICPMS values (daily differences ranged from $0.015-0.683 \mathrm{nM}$, the average was $0.216 \mathrm{nM}$ ). This difference indicates that the daily shipboard blank correction was underestimating the true system blank. Thus, shipboard data sets have been validated and corrected for the FIA system blank using the shorebased ICP-MS method of $W u$ and Boyle (1998) for dFe and dMn on replicate filtered, acidified samples that were returned to the University of Miami (Wu laboratory). Samples for shorebased determinations were filtered on board using identical methods as those for the FIA samples, and were stored in 1L LDPE bottles and acidified to $0.024 \mathrm{M}$ with $\mathrm{HCl}$ using ultrapure $6 \mathrm{~N} \mathrm{HCl}$ prior to analysis. The shipboard FIA blank was estimated by correlating the values obtained by shorebased ICP-MS Fe against each day's shipboard run of samples against their shipboard values and subtracting the derived offset from each sample that was run at sea. The four demi-station samples (USGT10-06, USGT11-15, -17, -23) were analyzed at the same time as full-depth stations, therefore the appropriate daily shipboard blank determined at the full depth stations was applied to the demi-stations. Details of the shipboard FIA-based dissolved Al methodology and discussion of the resultant distributions is presented in Measures et al (in this issue). Data are available and details of the FIA methodology are described at BCO-DMO website (http://osprey.bco-dmo.org/dataset.cfm?id=14219\&flag=viewa and http://osprey.bco-dmo.org/dataset.cfm?id=14220\&flag=viewa).

Dissolved Fe was also determined in replicate filtered water-column samples from a smaller subset of stations by several other shore-based laboratories, using a similar FIA method (Sedwick et al., 2005), two isotope dilution ICP-MS methods (Conway et al., 
2013; Wu and Boyle, 1998), and a batch pre-concentration ICPMS method (Biller and Bruland, 2012). While there are discernable differences between the analyzed values for samples where a direct comparison is possible (as discussed in the following section), all of the $\mathrm{dFe}$ data sets reveal consistent features along the sections.

\section{Results and Discussion}

\section{1. dFe values determined by different laboratories}

During the GEOTRACES GA03 cruises, dFe was determined in replicate water column samples from stations USGT10-09, USGT10-10 and USGT10-12 were by five different laboratories, using ICP-MS (Biller and Bruland, 2012; Conway et al., 2013; Wu and Boyle, 1998) and FIA (Measures et al., 1995; Sedwick et al., 2005). In addition, dFe was determined in samples from Stations USGT10-07, USGT10-10, and USGT11-20 by four labs, and the rest of the samples from the full-depth stations were analyzed by three labs. This comparison of analytical methodologies provides important information for the purpose of intercalibration, but a full discussion of the comparison is beyond the scope of this paper and will be discussed elsewhere. In summary, the one-sigma standard deviation of the $\mathrm{dFe}$ concentration data from the five laboratories is $0.16 \mathrm{nM}$ (RSD 13.4\%) at station USGT10-09 located near African continent and $0.06 \mathrm{nM}$ (RSD 12.5 \& $13.8 \%)$ at stations USGT11-10 \& -20 respectively, that are located in the open ocean. The higher standard deviation at station USGT10-09 located near African content could be due to the differences in the physiochemical speciation of iron near the coast, which might respond differently to the varying methodologies used in the five laboratories. Despite the differences between the data sets from the different laboratories (0.06-0.16 $\mathrm{nM}$ ), the dFe data reported in this study show consistent trends.

\subsection{Overview of $d F e$ and $d M n$ distribution along the North Atlantic zonal transect}

The distributions of $\mathrm{dFe}$ and $\mathrm{dMn}$ are presented in Figures 2 and 3, respectively, as contoured sections prepared using Ocean Data View (Schlitzer, 2012). These figures combine data from both cruises (USGT10 and USGT11). Two profiles (USGT10-12, USGT11-24) were collected at the repeat (crossover) sampling station located at the Tropical Eastern North Atlantic Time-Series Observatory (TENATSO) near the Cape 
Verde islands (Figure 1). In order to minimize loss of detail at the lowest concentrations, values of $\mathrm{dFe}>2.5 \mathrm{nM}$ and $\mathrm{dMn}>5.5 \mathrm{nM}$ that were measured at the hydrothermal plume site over the Mid-Atlantic Ridge are excluded from the contour plots. All of the dFe and $\mathrm{dMn}$ data presented here are archived and available at the Biological \& Chemical Oceanography Data Management Office (BCO-DMO) web site under the project name 'U.S. GEOTRACES North Atlantic Transect' (http://osprey.bcodmo.org/project.cfm?flag=view\&id=33\&sortby=project).

The $\mathrm{dFe}$ distributions reveal the impact of several sources (Figure 2). Enrichments of $\mathrm{dFe}$ at the surface indicate significant atmospheric deposition. In the subsurface waters, $\mathrm{dFe}$ maxima are a result of the remineralization process, as indicated by their coincidence with minima in dissolved oxygen concentration. Enrichments of $\mathrm{dFe}$ in the western basin $(>1 \mathrm{nM})$ at $600-1500 \mathrm{~m}$ depth correspond to the presence of Upper Labrador Sea Water. The largest $\mathrm{dFe}$ anomaly, with a concentration of $68 \mathrm{nM}$, is observed at station USGT11-16 $\left(26.1^{\circ} \mathrm{N}, 44.8^{\circ} \mathrm{W}\right)$, over the TAG hydrothermal site on the Mid-Atlantic Ridge.

The $\mathrm{dMn}$ distributions also reveal several input and transformation processes across the transect (Figure 3). In the surface waters, dust deposition (and photo reduction) result in elevated $\mathrm{dMn}$. Additional input of $\mathrm{dMn}$ is visible in both surface and sub-surface waters from reducing sediments in both the eastern and western basins. The largest $\mathrm{dMn}$ anomaly, with concentrations up to $33 \mathrm{nM}$, are seen at the TAG hydrothermal site corresponding to the dFe anomaly.

In the following sections, we will discuss the role of atmospheric deposition in driving surface water $\mathrm{dFe}$ concentrations (Section 3.3), then discuss the $\mathrm{dFe}$ minima associated with the chlorophyll maxima (Section 3.4), the dFe enrichment in the subsurface waters related to the oxygen minima (Section 3.5), the potential sources of $\mathrm{dFe}$ to the intermediate water (Section 3.6), and finally, the hydrothermal dFe input to the deep waters (Section 3.7). 


\subsection{The role of atmospheric deposition in driving surface water dFe concentrations}

Average mixed layer concentrations of dFe (0.18-1.01 nM), dMn (0.85-3.9 nM), and dAl (10.4-45.5 nM) across the North Atlantic study region are shown in Figure 4. These values represent the average concentration of each sample collected within the mixed layer at each station, including surface samples from the underway towed-fish and vertical profile samples collected using the trace metal clean rosette sampling system $(\mathrm{n}=1$ or 2 , Table.1). The mixed layer depth (MLD) is defined as the depth where the potential density change relative to the surface is $\geq 0.125 \mathrm{~kg} \mathrm{~m}^{-3}$. In addition to the density criterion, the temperature and salinity profiles were inspected at each station for uniformity within this layer, and where they were not uniform, the depth of any perturbation in the profile was chosen as the base of the mixed layer. The MLD's are shown in Table 1.

The average mixed layer $\mathrm{dFe}$ concentrations are slightly higher $(>0.6 \mathrm{nM})$ at the coastal stations USGT11-01 and USGT11-02 near the North American continent, and then decrease from the coastal stations to the offshore station USGT11-06 (Line W, the left panels of Figure 4). Average mixed layer dMn concentrations show a similar trend to $\mathrm{dFe}$ along this transect, suggesting that the coastal surface waters are enriched in both these elements. The average mixed layer dAl concentrations, in contrast, show lower values in coastal waters, rising to a maximum at Station USGT11-03, then decreasing slightly towards the offshore station USGT11-06. In addition to insignificant dAl input from the coast, the lower dAl values at station USGT11-01 \& -02 indicate low dust deposition, which is the main source of $\mathrm{dAl}$ to the surface water. The dAl maximum at Station USGT11-03 coincides with the cruise track crossing the Gulf Stream (also apparent in the shipboard ADCP data), which carries waters from the Caribbean that are more impacted by atmospheric deposition (Measures et al., this issue). The surface waters at Station USGT11-03 might thus be expected to have a higher concentration of $\mathrm{dFe}$, reflecting dust deposition further south; instead, surface dFe was lower than that measured at the coastal stations. The lower value is probably a result of the much shorter residence time of $\mathrm{dFe}$ in surface waters compared to $\mathrm{dAl}$ and the transit time from the deposition region to our sampling station. 
From Station USGT11-06, at the western edge of the North Atlantic Subtropical Gyre, the mixed layer $\mathrm{dFe}$ concentrations increase from $0.31 \mathrm{nM}$ to $0.88 \mathrm{nM}$ at Station USGT11-14 $\left(27.6^{\circ} \mathrm{N}, 49.6^{\circ} \mathrm{W}\right)$, and then decrease to $0.22 \mathrm{nM}$ at USGT11-23 $\left(18.4^{\circ} \mathrm{N}\right.$, $\left.26.8^{\circ} \mathrm{W}\right)$. The highest values we see are similar to those previously reported in nearby regions of the North Atlantic subtropical gyre $(>1 \mathrm{nmol} / \mathrm{kg}$ in the BATS region, Sedwick et al., 2005; $0.89 \mathrm{nmol} / \mathrm{kg}$ at $33^{\circ} \mathrm{N} 45^{\circ} \mathrm{W}$, Bergquist and Boyle, 2006; $0.81 \mathrm{nmol} / \mathrm{kg}$ at $20^{\circ} \mathrm{N} 45^{\circ} \mathrm{W}$, Fitzsimmons et al., 2013). In contrast, near the Cape Verde islands, the lower mixed layer dFe values (0.22-0.24 nM) observed at Stations USGT11-22 and USGT11-23, respectively, are slightly higher than values previously reported in this region (0.13-0.17 nmol/kg, Fitzsimmons et al., 2013; $0.13 \pm 0.07 \mathrm{nmol} / \mathrm{kg}$, Rijkenberg et al., 2012; $0.15 \mathrm{nmol} / \mathrm{L}$, Schlosser et al., 2014). It is also clear that the dAl and dFe concentrations are coupled in this region. There is a corresponding increase in mixed layer dAl concentrations across the subtropical gyre between Stations USGT11-10 and USGT11-23, and there is a positive correlation between $\mathrm{dFe}$ and dAl concentrations $\left(\mathrm{r}^{2}=\right.$ $0.78, \mathrm{n}=10$ ), a trend consistent with the hypothesis that dust input is a major source of $\mathrm{dFe}$ to surface waters in the North Atlantic subtropical gyre. In contrast, mixed layer $\mathrm{dMn}$ concentrations $(1.59 \pm 0.27 \mathrm{nM})$ at stations USGT11-10 through USGT11-23 are similar to those reported for this region and summarized by Shiller (1997) and do not vary significantly across the subtropical gyre. This is somewhat surprising since there is an eolian source for this element (Shiller, 1998), suggesting that the magnitude of dust input is decoupled from the dMn concentrations, perhaps as a result of photo reduction processes (Sunda et al., 1983; Sunda and Huntsman, 1994).

Interestingly, the $\mathrm{dFe}: \mathrm{dAl}$ ratio of the mixed layer in the subtropical gyre (USGT11-12 through USGT11-20) during the 2011 cruise shows a remarkably narrow range of $0.017-0.024 \mathrm{~mol} / \mathrm{mol}$, with an average value of $0.021 \pm 0.002 \mathrm{~mol} / \mathrm{mol}$. The $\mathrm{dFe}: \mathrm{dAl}$ ratio in the surface waters is representative of the net result of the competing processes of atmospheric input, dust dissolution, regeneration and removal of these elements, which occur over different time scales. Thus, the relatively constant dFe:dAl ratio in the subtropical gyre may reflect surface waters in regions that have recently been impacted by dust deposition, or, alternately, it may reflect quasi steady-state conditions in the surface mixed layer. 
Along the Mauritanian transect (Stations USGT11-24 through USGT10-09, Figure 1c), under the main Saharan dust plume, mixed layer dFe, dAl and dMn concentrations increase from offshore towards the coastal region, from 0.42 to $1.01 \mathrm{nM}$ (dFe), 20 to $34 \mathrm{nM}(\mathrm{dAl})$, and 1.8 to $3.5 \mathrm{nM}(\mathrm{dMn})$. It appears that the surface $\mathrm{dFe}$ values are once again controlled by atmospheric inputs, as demonstrated by the strong positive correlation (not shown) between $\mathrm{dFe}$ and $\mathrm{dAl}\left(\mathrm{r}^{2}=0.94, \mathrm{n}=5\right)$. However, increases of $\mathrm{dMn}$ along this transect are also consistent with a coastal source (Shiller, 1997), which might provide additional $\mathrm{dFe}$ to these waters. In fact, the strong positive correlation (not shown) between $\mathrm{dFe}$ and $\mathrm{dMn}\left(\mathrm{r}^{2}=0.75, \mathrm{n}=5\right)$ suggests that $\mathrm{dFe}$ (and presumably $\mathrm{dAl}$ as well) could be added into the water from coastal inputs.

Along the northerly transect from the Mauritanian shelf Station USGT10-10 to the European shelf Station USGT10-01 (Figure 4, right panels), the average mixed layer concentrations of $\mathrm{dFe}(0.80$ to $0.19 \mathrm{nM}), \mathrm{dMn}(3.0$ to $0.9 \mathrm{nM})$ and $\mathrm{dAl}(26$ to $10 \mathrm{nM})$ decrease. A similar trend was reported by Measures et al. (2008) and Ussher et al. (2013). The low concentrations near the European shelf likely reflect the lower dust inputs at this latitude. Our transect data show an isolated increase in $\mathrm{dFe}$ concentration $(0.85 \mathrm{nM})$, at Station USGT10-06 which is downwind of the Canary Islands, where surface dAl values were also elevated at $23 \mathrm{nM}$.

Between the high surface dFe concentrations of the sub-tropical gyre and the coastal Mauritanian section, there is a region of lower surface concentrations. This region corresponds to the cruise track crossing the southward flowing Canary Current. This localized decrease results from the intrusion of the low dFe northern source waters, which originate outside the main deposition region of the Saharan dust plume. Further details of the impacts of dust deposition to the surface ocean in this region are discussed in Measures et al., Shelley et al. (this issue).

\subsection{Dissolved Fe minima associated with deep chlorophyll maxima}

Near or below the base of the surface mixed layer, dFe minima were observed across the subtropical gyre, typically in association with deep chlorophyll maxima (DCM; data not shown). These features, previously described by Sedwick et al. (2005), 
Berquist and Boyle (2006), and Measures et al. (2008), are thought to reflect biological uptake and/or particle scavenging within the lower euphotic zone. Results of physical speciation measurements for $\mathrm{dFe}$ along this cruise transect (Fitzsimmons et al., in this issue) and throughout the subtropical North Atlantic (Fitzsimmons and Boyle, 2014) indicate that colloidal Fe $(0.02-0.2 \mu \mathrm{m})$ concentrations approach zero within the DCM, whereas soluble $\mathrm{Fe}(<0.02 \mu \mathrm{m})$ concentrations remain nearly constant. They discuss a variety of potential explanations for this including scavenging, biological uptake, or an absence of colloidal-sized ligands in this depth range.

In contrast, along Line $\mathrm{W}$, there were no $\mathrm{dFe}$ minima associated with elevated chlorophyll fluorescence, which, unlike the subtropical gyre, was fairly uniform over the surface mixed layer. Along this section, the $\mathrm{dFe}$ concentrations were fairly constant at $\sim 0.8 \mathrm{nM}$ throughout the upper $500 \mathrm{~m}$ of the water column. A possible explanation for the lack of $\mathrm{dFe}$ depletion in this region is limited biological uptake, given that that the sampling was carried out in November, a period of low ambient irradiance, and also when seasonal vertical mixing was occurring. Another possibility is the coastal $\mathrm{dFe}$ inputs, are masking any depletion due to biological activity. Colloidal Fe was higher at the Line $\mathrm{W}$ stations compared to the subtropical gyre stations, suggesting colloidal $\mathrm{Fe}$ inputs from sediment/shelf sources (Fitzsimmons et al., in this issue). Further consideration of the relationship between $\mathrm{dFe}$ and biological uptake are discussed by Fitzsimmons et al. (this issue).

\subsection{Enrichment of dFe in subsurface waters (central waters)}

\subsubsection{Sedimentary and remineralization inputs along the Mauritanian transect}

Elevated $\mathrm{dFe}$ concentrations $(>1.0 \mathrm{nM})$ were observed in the subsurface central water, which is defined as waters occupying a potential density range from $25.8 \mathrm{~kg} \mathrm{~m}^{-3}$ to $27.1 \mathrm{~kg} \mathrm{~m}^{-3}$ (neutral density $\gamma^{\mathrm{n}}=25.8-27.2 \mathrm{~kg} \mathrm{~m}^{-3}$, depth range $\sim 100-400 \mathrm{~m}$ ) between Stations USGT10-09 (coastal) and USGT11-24 (offshore) along the Mauritanian transect (Figure S1 in the Supplementary Material). This dFe enrichment is associated with low dissolved oxygen concentrations $(45-100 \mu \mathrm{mol} / \mathrm{kg}$ ), and thus the elevated $\mathrm{dFe}$ 
concentrations in the subsurface waters are likely derived from remineralization of organic material in the water column (Fitzsimmons et al., 2013; Wu et al., in this issue).

Near the coast at Stations USGT10-09 and USGT10-10, however, elevated dMn was also observed in these same subsurface waters (Figure 3). In this region, upwelling supports high biological production in surface waters, resulting in high export fluxes, accumulation of organic matter on the shelf/slope, and the development of reducing conditions in the sediments. These conditions lead to remobilization of Fe and $\mathrm{Mn}$ in sediment pore waters and subsequent release into the overlying water column (Landing and Bruland, 1980; Martin and Knauer, 1984). Since these water-column samples also had elevated ${ }^{228} \mathrm{Ra}$ concentrations, it is clear that these waters had recently been in contact with shelf/slope sediments (Charette et al., in this issue.).

Further offshore at Stations USGT10-07, USGT10-11 through USGT10-12, and USGT11-24, dFe enrichment was observed in subsurface waters without corresponding enrichments in dMn (Figures 2,3), suggesting that this dFe enrichment is not derived from sedimentary inputs. Instead, subsurface dFe concentrations show a positive correlation with the apparent oxygen utilization (AOU) (Figure 5) in the subsurface water mass Atlantic Equatorial Water (AEW), defined by Jenkins et al. (in this issue), and the enhanced $\mathrm{dFe}$ is thus attributed to remineralization alone. The AOU value represents the amount of the oxygen that has been consumed by remineralization of organic matter since the waters left the surface, whereas in-situ dFe concentration equals the preformed $\mathrm{dFe}$ plus any $\mathrm{dFe}$ released from organic matter remineralization, minus any $\mathrm{dFe}$ scavenged by particles. Thus, the dFe:AOU correlation plot reveals the net rate of $\mathrm{dFe}$ input to subsurface water, which includes the combined effect of remineralization input and removal by particle scavenging.

\subsubsection{The remineralization input across GEOTRACES GA03}

Remineralization likely exerts a primary control on the large scale distribution of $\mathrm{dFe}$ in subsurface waters, as suggested by the positive correlation between $\mathrm{dFe}$ and $\mathrm{AOU}$ throughout the transect (Figure 5). However, the dFe concentrations in the water column reflect not only $\mathrm{dFe}$ input from remineralization, but also dFe input from sedimentary 
sources, as discussed in Section 3.3.1. Thus, in order to evaluate just the remineralization input within the central water along GA03, stations have been excluded where $\mathrm{dMn}$ concentrations indicate significant sedimentary inputs. As identified in the Section 3.3.1, Stations USGT10-09 and USGT10-10 clearly show sedimentary input from the eastern margin near the African coast, and Stations USGT11-01 and USGT11-02 show similar features along the western margin of the basin. These stations are thus excluded from further discussion. We have also divided the central water of the offshore stations into two groups, based on the optimum multi parameter analysis (OMPA) method presented by Jenkins et al. (this issue.). Those results show that the central water of offshore stations USGT10-07, USGT10-10 through USGT10-12, and USGT11-24 are dominated $(>60 \%)$ by the presence of Atlantic Equatorial Water (AEW), whereas those of the subtropical gyre stations USGT11-03 through USGT11-23 are dominated ( $>60 \%)$ by North Atlantic Central Water (NACW). Based on these criteria, Figure 5 shows that for the $\mathrm{AEW}$, the slope of the $\mathrm{dFe}$ :AOU relationship is $0.0046 \pm 0.0006 \mathrm{nmol} / \mu \mathrm{mol}\left(\mathrm{n}=21, \mathrm{r}^{2}=\right.$ 0.74 ), which is similar to the slope of the dFe:AOU relationship for the NACW of 0.0041 $\pm 0.0003 \mathrm{nmol} / \mu \mathrm{mol}\left(\mathrm{n}=95, \mathrm{r}^{2}=0.69\right)$. This implies that the net remineralization rates of $\mathrm{dFe}$ in these two central waters are similar.

Using the slope of the $\mathrm{dFe}: \mathrm{AOU}$ data and a modified oxygen consumption ratio of 1.6 moles $\mathrm{O}_{2}$ per mole of carbon remineralized (Martin et al., 1987), we estimate the net Fe:C ratio of the remineralization process is $6.6 \pm 0.5 \mu \mathrm{mol} / \mathrm{mol}$ in the NACW, and $7.4 \pm$ $1.0 \mu \mathrm{mol} / \mathrm{mol}$ in the AEW, within the range of those reported by Ussher et al. (2013). These Fe:C ratios are somewhat lower than estimates from other studies in the North Atlantic (7-12 $\mu \mathrm{mol} / \mathrm{mol}$, Sunda, 1997; $11 \pm 1 \mu \mathrm{mol} / \mathrm{mol}$, Bergquist and Boyle 2006; 9.6$12.4 \mu \mathrm{mol} / \mathrm{mol}$, Fitzsimmons et al., 2013). However, our calculated ratios are higher than values previously reported using data from the North Pacific (3-4 $\mu \mathrm{mol} / \mathrm{mol}$, Sunda 1997; $3.7 \mu \mathrm{mol} / \mathrm{mol}$, Bergquist and Boyle, 2006, calculated from the data of Martin et al., 1989), or from the Southern Ocean $(\sim 2 \mu \mathrm{mol} / \mathrm{mol}$, Sunda, 1997). Higher ratios in the North Atlantic have been attributed to the higher Fe concentrations in organic matter in the North Atlantic Ocean, driven by higher dFe concentrations in surface waters of this region (Bergquist and Boyle, 2006; Fitzimmons et al., 2013). 
The Fe:C ratio in the water column can also be used to infer the scavenging removal of $\mathrm{dFe}$ by comparing it to the elemental $\mathrm{Fe}: \mathrm{C}$ stoichiometry of phytoplankton collected during this cruise. Using a cellular Fe:P ratio of $\sim 5 \times 10^{-3} \mathrm{~mol} / \mathrm{mol}$; (Twining and Baines, 2013), a modified Redfield AOU:P ratio of $163 \mathrm{~mol} / \mathrm{mol}$ (Martin et al., 1987), and a C:AOU ratio of 1.6 we estimate that the Fe:C ratio that should be released during remineralization of phytoplankton biomass would be $\sim 49 \mu \mathrm{mol} / \mathrm{mol}$. This value is within the range of the $\mathrm{Fe}: \mathrm{C}$ values $(20-60 \mu \mathrm{mol} / \mathrm{mol})$ measured in organic particles that were collected during these GEOTRACES cruises, using the synchrotron radiation X-ray fluorescence (SXRF) method (Twining et al., pers. comm.). This calculated regeneration ratio is around 5 times higher than the $\mathrm{dFe}: \mathrm{C}$ ratio inferred for the NACW $(6.6 \mu \mathrm{mol} / \mathrm{mol})$ and AEW $(7.4 \mu \mathrm{mol} / \mathrm{mol})$, as derived from the AOU and dFe data. This result reinforces the notion that a significant proportion (perhaps as much as 63-90\%) of the Fe released during remineralization of organic matter has been removed from the water column via scavenging. Furthermore, this scavenging removal appears to be fairly constant throughout the gyre. The time scale of this scavenging process is unknown and it is feasible that it is "instantaneous" upon remineralization, which appears to occur for $\mathrm{Pb}$ and $\mathrm{Pb}-210$ scavenged onto surface biogenic matter but at most minimally released upon their sinking and remineralization (Bacon et al., 1976; Shen and Boyle, 1988).

Note that the intercepts of the linear fit of the dFe vs. AOU data, which represents preformed dFe (Figure 5), are different for NACW $(0.17 \pm 0.02 \mathrm{nM} \mathrm{dFe})$ and AEW (0.35 $\pm 0.10 \mathrm{nM} \mathrm{dFe}$ ). Since the concentrations of preformed soluble Fe are similar in these water masses (0.11-0.16 nmol/kg, Fitzsimmons et al., in this issue), the difference between the inferred preformed $\mathrm{dFe}$ concentrations likely reflects differences in the concentrations of the colloidal Fe fraction, as discussed further by Fitzsimmons et al. (in this issue).

\subsubsection{Temporal variations at the TENATSO station}

The TENATSO station was sampled during both cruises (Stations USGT10-12 in 2010 and USGT11-24 in 2011). While the dFe concentrations in deep waters are very similar between these two occupations, small differences are observed at shallower depths $(<500 \mathrm{~m})$, which is consistent with changes in the hydrographic parameters 
(Figure 6). The slight differences of surface dFe (0.35 nM at USGT10-12 vs. $0.45 \mathrm{nM}$ at USGT11-24) are likely related to differences in cumulative dust deposition prior to each cruise, as supported by differences in surface dAl concentrations (15 nM USGT10 vs. 19 nM USGT11). In fact, direct measurements of dust load in Cape Verde island during 1991 to 1994 indicate a pronounced seasonal pattern with maximum dust loads observed during winter, $\sim 20 \mu \mathrm{g} \mathrm{m}^{-3}$ in November and $\sim 50 \mu \mathrm{g} \mathrm{m}^{-3}$ in December (Chiapello et al., 1995). Thus the higher $\mathrm{dFe}$ value $(0.45 \mathrm{nM})$ at Station USGT11-24 that was obtained during early December might show a higher dust input than at Station USGT10-12 that was obtained during early November. A similar response has been observed in Sargasso Sea (Sedwick et al., 2005). The OMPA results also indicate a change in the central water composition between the two occupations, with NACW dominating during the 2010 cruise and AEW dominating during the 2011 cruise (Jenkins et al., in this issue.). In the central waters (150-285 m), the dFe concentrations at USGT11-24 (AEW) are higher than those at USGT10-12 (NACW), consistent with our suggestion of more pre-formed $\mathrm{dFe}$ in AEW relative to NACW. In addition, the dissolved oxygen concentrations at 150$285 \mathrm{~m}$ are slightly higher during the 2010 cruise $(80 \pm 13 \mu \mathrm{mol} / \mathrm{kg})$ than the 2011 cruise (69 $\pm 7 \mu \mathrm{mol} / \mathrm{kg}$ ), implying lower AOU and thus less remineralized $\mathrm{dFe}$ than during 2010. Furthermore, previous dFe data from a 2008 sampling of TENATSO (Station 27 from OC449-2 project; Fitzsimmons et al., 2013) shows good agreement with the dFe concentrations at station USGT11-24 (Figure 6). Since this is clearly a region of great variations in the upper waters, repeated observations here would be worthwhile.

\subsection{Potential sources of dFe to the Intermediate Water}

\subsubsection{The dFe enrichment in Labrador Sea Water}

In the western basin, from the coastal stations to the offshore stations (Stations USGT11-01 through USGT11-08), the deep dFe maximum (DFM) gradually deepens from $\sim 600 \mathrm{~m}$ to $\sim 1500 \mathrm{~m}$ (Figures 2,7 ). Since the dFe maxima (red color in Figure 7) are deeper than maxima in AOU or macronutrients (blue color in Figure 7, subsurface water), $\mathrm{dFe}$ enrichment at this depth most likely reflects an external $\mathrm{dFe}$ input. The depth range of the DFM corresponds to the presence of Upper Labrador Sea Water (ULSW, 
$27.8<$ neutral density $\left(\gamma^{\mathrm{n}}\right)<27.897$; Toole et al., 2011), which is characterized by high CFC-11 values (Figure 7). ULSW is one of the shallowest contributors to the North Atlantic Deep Water, and is formed by deep convection in the central western Labrador Sea in late winter (Tally and McCartney, 1982). From there, it flows southward along the eastern boundary of North America, as part of the Deep Western Boundary Current (Talley and McCartney, 1982; Dickson and Brown, 1994; Smethie et al., 2007; LeBel et al., 2008; Bower et al. 2009, 2011).

The DFM (1.1 $\pm 0.2 \mathrm{nM}$ dFe, stations USGT11-01 through USGT11-08) in ULSW could reflect either significant dust deposition in its formation region (high preformed $\mathrm{dFe}$ ), or remineralization processes or sedimentary inputs along its advective flow path. Although run-off from Greenland ice melt has been shown to have high $\mathrm{dFe}$ (Bhatia et al., 2013), it is unlikely that much of this material makes its way into the formation region of the ULSW as low salinities associated with such a source would probably inhibit convection. There are no available dFe data from the Labrador Sea, so we cannot address the preformed $\mathrm{dFe}$ concentration directly. Instead, we can estimate preformed $\mathrm{dFe}$ concentrations from dust deposition using the dAl values that Hall and Measures (1998) report in the water column between $250 \mathrm{~m}$ and $2000 \mathrm{~m}$ depth (6.9-7.7 $\mathrm{nM}$ ), which was identified as Labrador Seawater during an August 1993 occupation. We can estimate preformed $\mathrm{dFe}$ by assuming that the $\mathrm{dFe}: \mathrm{dAl}$ ratio of the surface water $(0.021 \pm 0.002 \mathrm{~mol} / \mathrm{mol}$, Section 3.1) in the subtropical gyre is similar to the ratio in the Labrador Sea. Using this ratio, we would estimate a dFe concentration of $0.14-0.16 \mathrm{nM}$, which is only $15-20 \%$ of the dFe concentration in ULSW at USGT11-01 through USGT11-08 (1.1 nM). Given the relatively short residence time of Fe compared to $\mathrm{Al}$ in surface waters, it is likely that this $\mathrm{dFe}$ : $\mathrm{dAl}$ ratio would be higher in a region of high dust input, leading us if anything to overestimate the preformed $\mathrm{dFe}$ in the surface waters of the LSW formation region. In addition to the preformed dFe calculated above, we must consider the potential for remineralized dFe along the advective flow path of the ULSW. To estimate this, we use the dFe:AOU remineralization ratio $(0.0041-0.0046 \mathrm{nmol} / \mu \mathrm{mol})$ from Section 3.5.2 and an AOU value of $61.7 \pm 6.5 \mu \mathrm{mol} / \mathrm{kg}$ in ULSW. These values suggest a net $\mathrm{dFe}$ addition to the water mass of $0.25-0.28 \mathrm{nM}$, which is only $\sim 25 \%$ of the 
$\mathrm{dFe}$ level in ULSW. Thus, using estimates of the preformed dFe and regenerated dFe, we calculate a total $\mathrm{dFe}$ concentration of $0.34-0.47 \mathrm{nM}$, which is only $\sim 45 \%$ of the $\mathrm{dFe}$ concentration observed in the ULSW $(1.1 \mathrm{nM})$.

We thus conclude that there is an additional source of $\mathrm{dFe}$, presumably acquired from continental margin sediments along the flow path of the ULSW. This dFe source is

consistent with the slightly elevated dMn in the ULSW (Figure 3), and the ${ }^{228} \mathrm{Ra}$ activities that indicate this water mass has been in contact with sediments within the last 30 years (Charette et al., in this issue.). Measures et al., (this issue) also conclude that a sedimentary input is responsible for the elevated dAl concentrations seen in the ULSW $(13.3 \pm 1.6 \mathrm{nM}$, stations USGT11-01 through USGT11-08, $\mathrm{n}=18)$ when compared to the 6.9-7.7 nM dAl measured in the Labrador Sea by Hall and Measures, 1998).

\subsubsection{Lack of dFe in the Mediterranean Outflow Water (MOW)}

Despite the fact that there is a large amount of dust deposition into the Mediterranean, Figure 2 shows that there is no significant elevation of $\mathrm{dFe}$ in the Mediterranean Outflow Water (MOW) relative to dAl value (Measures et al., this issue). The MOW is formed from the Mediterranean Water that enters the North Atlantic as a dense overflow through the Strait of Gibraltar, and entrains ambient water as it sinks to a neutral density plume at around $1200 \mathrm{~m}$ depth (Talley et al., 2011). The MOW is also distinguished by its high salinity and high dAl concentrations (Measures et al., this issue.). The maximum proportion of the MOW is seen at Station USGT10-01, and the salinity and dAl value of the MOW gradually decrease as it spreads out and mixes with the waters in the North Atlantic subtropical gyre, which is observed clearly from stations USGT10-01 to USGT10-08 in the North-South section (Measures et al., this issue.). However, dFe concentrations are not elevated in this water mass (Figure 2), even though dFe was almost certainly added to Mediterranean surface waters via dust deposition, suggesting that such dust-derived $\mathrm{dFe}$ had been mostly removed by biological uptake and/or particle scavenging prior to the MOW entering the North Atlantic basin. 


\subsection{Hydrothermal Fe transport in the deep waters}

The most dramatic feature of the zonal dFe distribution is the elevated concentration observed in the hydrothermal plume over the Trans-Atlantic Geotraverse (TAG) site on the Mid-Atlantic Ridge (MAR). The high concentrations of dFe (12.3$68.1 \mathrm{nM})$ and $\mathrm{dMn}(7.2 \mathrm{nM}-33 \mathrm{nM})$ were located between $3200 \mathrm{~m}$ and $3500 \mathrm{~m}$ depth at Station USGT11-16 (Figure 8a, 8b). The depths of the dFe maxima correspond to the depths of the elevated $\delta^{3} \mathrm{He}$, indicative of hydrothermal inputs (Jenkins et al., this issue). Also at this station, elevated particle beam attenuation coefficient $(\mathrm{Cp})$ values at these same depths indicate a significant number of particles in the plume. The mechanisms leading to the water column $\mathrm{dFe}$ concentration of $>60 \mathrm{nM}$ over the TAG site will be discussed in a separate paper (Fitzsimons et al. in prep.), and here we will only discuss the influence of the plume on the surrounding deep waters.

The vertical profile of $\mathrm{dFe}$ at station USGT11-14 (500 km to the west of the MAR) shows slightly higher $\mathrm{dFe}$ concentrations between $1500 \mathrm{~m}$ and $3000 \mathrm{~m}$ depth than values at Station $18(500 \mathrm{~km}$ to the east of the MAR; Figure $8 \mathrm{c})$. This trend is also visible in the $\mathrm{dMn}$ data (Figure $8 \mathrm{~d}$ ), in the $\delta^{3} \mathrm{He}$ profiles (Jenkins et al., in this issue.), and in the dAl data (Measures et al., in this issue). We note, however, that since there are numerous known active hydrothermal sites along the MAR (InterRidge Vents Database $2.2 \mathrm{http}: / /$ www.interridge.org/irvents/), the dFe anomaly we see at Station USGT11-14 might be an advected feature originating from a distal hydrothermal vent field on the MAR.

Hydrothermal vents have not historically been considered as a major source of $\mathrm{dFe}$ to the deep ocean, because it was thought that much of the Fe vented in hydrothermal systems was precipitated close the vent site (German et al. 1991). However, recent dFe distributions from each of the oceans shows a significant enhancement of $\mathrm{dFe}$ in deep waters 'downstream' of hydrothermal vents (Tagliabue et al., 2010; Wu et al., 2011; Saito et al., 2013), which led Toner et al (2012) to hypothesize that a significant proportion of the hydrothermal Fe is escaping the near-field hydrothermal areas and contributing to the abyssal ocean $\mathrm{dFe}$ inventory (the 'leaky vent' hypothesis). In the South Pacific, Fitzsimmons et al. (in review) have verified this hypothesis by 
demonstrating distal transport of hydrothermal $\mathrm{dFe}$ thousands of kilometers from the vent site. However, along the North Atlantic zonal section sampled during the 2011 cruise, hydrothermal $\mathrm{dFe}$ anomalies are observed only $\sim 500 \mathrm{~km}$ west of MAR. This raises the question as to why the $\mathrm{dFe}$ signal from this hydrothermal source is only visible for $\sim 500$ $\mathrm{km}$ in the North Atlantic, versus the thousands of kilometers in the South Pacific, given that the $\mathrm{dFe}$ concentrations in the hydrothermal vent fluids at TAG $(\sim 5 \mathrm{mM}$, Gamo et al., $1996)$ and in the southern East Pacific Rise (0.5-12 mM, Charlou et al., 1996) are apparently similar. One possibility is that the volume of endmember hydrothermal inputs might be different in these oceans. Another possibility is that this may reflect faster $\mathrm{Fe}$ (II) oxidation kinetics (Field and Sherrell, 2000) and faster removal from the water as particulates in the Atlantic compared to the South Pacific, since oxygen concentrations in South Pacific Ocean are much lower than those in the North Atlantic deep waters. Fitzsimmons et al. (this issue) suggest that physical speciation may also play a role since the soluble fraction of $\mathrm{Fe}(<0.02 \mathrm{um})$ appears to be the species that more efficiently "leaks" from hydrothermal vents. Also, it is possible that our section is not aligned with the flow path of the plume and the rapid meridional advection rates in the deep western Atlantic might erase the hydrothermal signal by dilution.

\section{Summary}

High-resolution measurements of the dFe distribution across GEOTRACES GA03 in the North Atlantic Ocean reveal several major sources of dFe to the North Atlantic basin. Enrichments of $\mathrm{dFe}$ at the surface suggest significant atmospheric deposition, since the $\mathrm{dFe}$ enrichments are strongly correlated with enrichments in dAl. In the subsurface waters, dFe maxima are strongly associated with minima in dissolved oxygen, indicating the addition of iron to these waters via remineralization processes. In addition, sedimentary inputs to the subsurface waters appear to be important, particularly near the African coast. The ratio of $\mathrm{dFe}$ to AOU, when combined with the measured stoichiometric composition of surface matter, suggests that a significant proportion of remineralized $\mathrm{dFe}(\sim 63-90 \%)$ is subsequently removed from the water column by particle scavenging. The extent of $\mathrm{dFe}$ remineralization and the $\mathrm{Fe}: \mathrm{C}$ regeneration ratio appear relatively constant across much of the central North Atlantic basin. In the western region, 
the dFe enrichments in ULSW appear to reflect sedimentary inputs along the advective flow path of the ULSW, as it transits the North American shelf region. The largest $\mathrm{dFe}$ anomaly $(>60 \mathrm{nM})$ was observed in the neutrally buoyant hydrothermal plume sampled over the TAG site on the MAR, with this hydrothermal dFe anomaly discernible $\sim 500 \mathrm{~km}$ to the west of the ridge axis.

\section{Acknowledgement}

We wish to thank the Captain and crew of the R/V Knorr and the Scripps technical support staff for their professional help in ensuring a successful expedition. We would also like to acknowledge the support provided by the Scripps Ocean Data Facility (SIO ODF, Mary Johnson, Rob Palomares, Courtney Schatzman and Melissa Miller) in providing the high quality hydrographic parameters and shipboard data management, and the Chief Scientist Dr. Jenkins and Dr. Boyle, and other PIs for making their data available and compiling the cruise data sets. We also thank two anonymous reviewers and Dr. Boyle as the editor, whose suggestions helped improve both our presentation of the data and the manuscript. Also we would like to thank Dr. Hummon for her help with interpreting the ADCP data, Dr. Hayes for the calculation of $\mathrm{Cp}$ value for this project, and Maxime Grand and Dr. Karen Selph for fruitful discussions and help with editing and polishing an earlier version of this manuscript.

Funding for ship-time, sampling operations, and hydrography data were provided by NSF grants to the GEOTRACES GA03 Management team of W. Jenkins (OCE0926423), E. Boyle (OCE-0926204), and G. Cutter (OCE-0926092). This work was

supported by NSF awards OCE-0928741 and OCE-1137812 to CIM, and OCE-0927285 to PNS. This is SOEST contribution number 9173. 


\section{Figure captions:}

Figure 1. Map of the GEOTRACES GA03 North Atlantic Cruise transects sampling area and geographic features in the North Atlantic Ocean. Full depth stations are indicated by circles, and "demi" stations (upper $1000 \mathrm{~m}$ ) are indicated by inverse triangles. (A) All transects (USGT10 in black and USGT11 in white), (B) Western margin, and (C) Eastern margin. The crossover station is shown as a yellow square (full depth station).

Figure 2. The dFe distribution (nM) overlaid with AOU ( $\mu \mathrm{mol} / \mathrm{kg})$ : the upper panels show the upper $1000 \mathrm{~m}$, and the lower panels show the full depth range of sampling. The bathymetry used was the Global High Resolution (GlobHR) of ODV software. Black dots show the sampled depth for dFe. Station numbers are shown at the bottom of each cast (USGT10 in blue, USGT11 in red). (A) The E-W transect from Line W to Mauritania combined with cruises USGT10 and USGT11. (B) The N-S transect in Eastern North Atlantic region (USGT10-01 through USGT10-08). Note that the Mid-Atlantic Ridge station was omitted from these plots (see text for explanation). For the color version of this figure, the reader is referred to the online version of this article.

Figure 3. The dMn distribution (nM) overlaid with the neutral density $\left(\mathrm{\gamma}^{n}, \mathrm{~kg} / \mathrm{m}^{3}\right)$ : the upper panels show the upper $1000 \mathrm{~m}$, and the lower panels show the full depth range sampled. The bathymetry used was the Global High Resolution (GlobHR) of ODV software. Black dots show the sampled depth for dMn. The layout of this figure is same as Figure 2. The water masses (NACW, AEW, ULSW, CLSW, ISOW, DSOW, AABW: see text for definitions) are characterized by neutral density as defined by Jenkins et al., (this issue). Note that the Mid-Atlantic Ridge station was omitted from these plots (see text for explanation). For the color version of this figure, the reader is referred to the online version of this article. 
Figure 4. The averaged trace metal concentrations in the mixed layer depth during USGT10 cruise (black circles) and USGT11 cruise (white squares). Left panels (Line W and the rest of stations in E-W transect) plotted by longitude (x-axis), and right panels (USGT10-01 through -09) are plotted with latitude (x-axis). (A) dFe (nM), (B) dMn $(\mathrm{nM})$, and $(\mathrm{C}) \mathrm{dAl}(\mathrm{nM})$. Stations numbers are shown on the dFe plots (the station number during USGT10 is shown with * symbol).

Figure 5. The relationship between AOU $(\mu \mathrm{mol} / \mathrm{kg})$ and $\mathrm{dFe}(\mathrm{nM})$ of the NACW (black circle, Stations USGT10-01 to -06 and Stations USGT11-03 to -23), the AEW (orange square, Stations USGT10-07, -11, -12 and USGT11-24), the African coastal region (USGT10-09 and -10), and the American coastal region (USGT11-01 and -02).

Figure 6. Vertical profiles upper 1000m of (A) Temperature, (B) Salinity (psu), (C) Oxygen $(\mu \mathrm{mol} / \mathrm{kg})$, (D) Phosphate $(\mu \mathrm{mol} / \mathrm{kg}),(\mathrm{E}) \mathrm{dFe}(\mathrm{nM})$ and $(\mathrm{F})$ the T-S diagram at TENATSO station. Data from GT10-12 are indicated by white squares and GT11-24 by black circles. Also shown are data from Fitzsimmons et al. (2013)(black line).

Figure 7. The vertical profiles upper $2000 \mathrm{~m}$ in Line W (Figure 1b) of AOU $(\mu \mathrm{mol} / \mathrm{kg}$ ), Silicate $(\mu \mathrm{mol} / \mathrm{kg}), \mathrm{dFe}(\mathrm{nM}), \mathrm{dMn}(\mathrm{nM})$, and CFC-11 (pmol/ $/ \mathrm{kg})$. Oxygen minimum depth and Labrador Sea Water (LSW) are highlighted with blue and red box, respectively. (A) Stations GT11-01 and -02, (B) Stations GT11-03 and -06, and (C) Stations GT11-05, -08 , and -10 .

Figure 8. The vertical profiles of (A) dFe and (B) dMn at Station USGT11-16. The profiles of (C) dFe and (D) dMn at Stations USGT11-16 (black circles), USGT11-14 (west of USGT11-16, white circles), and USGT11-18 (east of USGT11-16, cross symbols). 
Table 1. Mixed layer depths (m) during GEOTRACES GA03 transect. "n" shows the number of samples within the mixed layer depth.

\begin{tabular}{|c|c|c|c|c|c|}
\hline Station & $\begin{array}{c}\text { Mixed layer } \\
\text { depth (m) }\end{array}$ & $\mathrm{n}$ & Station & $\begin{array}{c}\text { Mixed layer } \\
\text { depth (m) }\end{array}$ & $\mathrm{n}$ \\
\hline USGT10-01 & 24 & 2 & USGT11-01 & 30 & 2 \\
\hline USGT10-02 & 49 & 2 & USGT11-02 & 35 & 2 \\
\hline USGT10-03 & 35 & 2 & USGT11-03 & 28 & 1 \\
\hline USGT10-05 & 31 & 2 & USGT11-05 & 41 & 2 \\
\hline USGT10-06 & 41 & 1 & USGT11-06 & 41 & 1 \\
\hline USGT10-07 & 35 & 2 & USGT11-08 & 32 & 2 \\
\hline USGT10-08 & 35 & 2 & USGT11-10 & 40 & 2 \\
\hline USGT10-09 & 28 & 2 & USGT11-11 & 60 & 2 \\
\hline USGT10-10 & 32 & 1 & USGT11-12 & 41 & 2 \\
\hline USGT10-11 & 30 & 2 & USGT11-13 & 45 & 2 \\
\hline \multirow[t]{11}{*}{$030110-12$} & 38 & 2 & USGT11-14 & 41 & 2 \\
\hline & & & USGT11-15 & 50 & 2 \\
\hline & & & USGT11-16 & 41 & 2 \\
\hline & & & USGT11-17 & 50 & 2 \\
\hline & & & USGT11-18 & 40 & 2 \\
\hline & & & USGT11-19 & 61 & 2 \\
\hline & & & USGT11-20 & 41 & 1 \\
\hline & & & USGT11-21 & 41 & 2 \\
\hline & & & USGT11-22 & 51 & 2 \\
\hline & & & USGT11-23 & 51 & 2 \\
\hline & & & USGT11-24 & 40 & 2 \\
\hline
\end{tabular}




\section{References:}

Bacon, M.P., Spencer, D.W., Brewer, P.G. $1976 .{ }^{210} \mathrm{~Pb} /{ }^{226} \mathrm{Ra}$ and ${ }^{210} \mathrm{Po} /{ }^{210} \mathrm{~Pb}$ disequilibria in seawater and suspended particulate matter. Earth and Planetary Science Letters 32:277-296, doi: 10.1016/0012-821X(76)90068-6.

Bergquist, B.A. and Boyle, E.A., 2006, Dissolved iron in the tropical and subtropical Atlantic Ocean. Global Biogeochemical Cycles, 20, GB1015, doi:10.1029/2005GB002505.

Bhatia, M.P., Kujawinski, E.B., Das, S.B., Breier, C.F., Henderson, P.B., Charette, M.A. 2013. Greenland meltwater as a significant and potentially bioavailable source of iron to the ocean. Nature geoscience 274-278. doi: 10.1038/NGEO1746.

Biller, D., Bruland, K.W., 2012. Analysis of Mn, Fe, Co, Ni, Cu, Zn, Cd, and Pb in seawater using the Nobias-chelate PA1 resin and magnetic sector inductively coupled plasma mass spectrometry (ICP-MS). Marine Chemistry 130-131. 12-20.

Bower, A.S., Lozier, M.S., Gary, S.F., Boning, C.W., 2009. Interior pathways of the North Atlantic meridional overturning circulation. Nature 459, 247.

Bower, A., Lozier, S., Gary,S. 2011. Export of Labrador Sea Water from the subpolar North Atlantic: A Lagrangian perspective. Deep-Sea Research II. 1798-1818.

Boyle, E. 1997. What controls dissolved iron concentrations in the world ocean?- a comment. Marine Chemistry 57. 163-167.

Boyd, P.W., Ellwood, M.J., 2010. The biogeochemical cycle of iron in the ocean. Nature Geoscience 3. 675-682, doi:10.1038/NGEO964.

Brown, M.T., Landing, W.M., Measures, C.I. 2005. Dissolved and particulate Fe in the western and central North Pacific: Results from the 2002 IOC cruise. Geochem. Geophys. Geosyst., 6, Q10001, doi:10.1029/2004GC000893. 
Bruland, K.W., Orians, K.J., Cowen, J.P. 1994. Reactive trace metals in the stratified central North Pacific. Geochimica et Cosmochimica Acta. 58. 3171-3182.

Buck, K.N., Sohst, B., Sedwick, P.N. The organic complexation of dissolved iron along the U.S. GEOTRACES North Atlantic Section. In this issue.

Charlou, J., Fouquet, Y., Donval, J., Auzende, J., Jean-Baptiste, P., Stievenard, M. and Michel, S. (1996). Mineral and gas chemistry of hydrothermal fluids on an ultrafast spreading ridge: East Pacific Rise, $17^{\circ}$ to $19^{\circ} \mathrm{S}$ (Naudur cruise, 1993) phase separation processes controlled by volcanic and tectonic activity. Journal of Geophysical Research 101: doi: 10.1029/96JB00880. issn: 0148-0227.

Charette, M.A., P.J. Morris, P.B. Henderson, and W.S. Moore. Radium Isotopes as Tracers of Boundary Exchange Processes Along the US GEOTRACES North Atlantic Zonal Transect. DSR II. 2014.

Chiapello, I., Bergametti, G., Gomes, L., Chatenet, B., Dulac, F., Pimenta, J., Santos Suares, E. 1995. An additional low layer transport of Sahelian and Saharan dust over the North-Eastern Tropical Atlantic. Geophysical Research Letters 22. 3191-3194.

Conway, T.M., Rosenberg, A.D., Adkins, J.F., John, S.G., 2013. Analytica Chimica Acta 793. 44-52.

Conway, T.M., John, S.G., Quantification of sources of dissolved iron to the North Atlantic Ocean. Nature. in press.

Croot, P.L., Streu, P., Baker, A.R., 2004. Short residence time for iron in surface seawater impacted by atmospheric dry deposition from Sahara dust events. Geophysical Research Letters 31. L23S08, doi:10.1029/2004GL020153.

Cutter, G., and K. W. Bruland. 2012. Rapid and noncontaminating sampling system for trace elements in global ocean surveys. Limnology and Oceanography: Methods 10: 425-436, doi:10.4319/1om.2012.10.425.

Dickson, R.R., Brown, J. 1994. The production of North Atlantic Deep Water: Sources, rates, and pathways. Journal of Geophysical Research: Oceans 99. 12319-12341. 
Duce, R.A et al., 1991. The atmospheric input of trace species to the World Ocean, Global Biogeochem. Cycles 5. 193-259.

Falkowski, P.G. 1997. Evolution of the nitrogen cycle and its influence on the biological sequestration of $\mathrm{CO} 2$ in the ocean, Nature 387, 272-275.

Field, M.P., Sherrell, R.M. 2000. Dissolved and particulate Fe in a hydrothermal plume at $9^{\circ} 45^{\prime}$ N, East Pacific Rise: Slow Fe (II) oxidation kinetics in Pacific plumes. Geochimica et Cosmochimica Acta, 64, 619-628.

Fitzsimmons, J.N. and Boyle E.A. 2014. Both soluble and colloidal iron phases control dissolved iron variability in the tropical North Atlantic Ocean. GCA 125: 539-550.

Fitzsimmons, J.N., Zhang, R., Boyle, E.A., 2013. Dissolved iron in the tropical North Atlantic Ocean. Marine Chemistry 154. 87-99.

Fitzsimmons, J.N., Carrasco, G.G., Wu, J., Hatta, M., Measures, C.I., Conway, T.M., John, S.G., Boyle, E.A., Partitioning of dissolved iron and iron isotopes into soluble and colloidal phases along the U.S. GEOTRACES North Atlantic Zonal Transect, in this issue.

Fitzsimmons, J.N., Boyle, E.A., Jenkins, W.J., Distal transport of dissolved hydrothermal iron in the deep South Pacific Ocean. in review.

German, C.R., Campbell, A.C., Edmond, J.M. 1991. Hydrothermal scavenging at the Mid-Atlantic Ridge: Modification of trace element dissolved fluxes. Earth and Planetary Science Letters. 107. 101-114.

Hall, I.R., Measures, C.I. 1998. The distribution of Al in the IOC stations of the North Atlantic and Norwegian Sea between $52^{\circ}$ and $65^{\circ}$ North. Marine Chemistry 61. 6985.

Husar, R.B., Prospero, J.M., Stowe, L.L. 1997. Characterization of tropospheric aerosols over the ocean with the NOAA advanced very high resolution radiometer optical thickness operational product. Journal of Geophysical Research 102. 16889-16909. 
Jenkins, Smethie, Boyle and Cutter, Water Mass Analysis for the U.S. GEOTRACES North Atlantic Sections. In this issue.

Johnson, K.S., Gordon, R.M., Coale, K.H. 1997. What controls dissolved iron concentrations in the world ocean? Marine Chemistry 57, 137-161.

Gamo, T., Chiba, H., Masuda, H., Edmonds, H., Fujioka, K., Kodama, Y., Nanba, H. and Sano, Y. (1996). Chemical characteristics of hydrothermal fluids from the TAG mound of the mid-Atlantic Ridge in August 1994: implications for spatial and temporal variability of hydrothermal activity. Geophysical Research Letters 23: doi: 10.1029/96GL02521. issn: 0094-8276.

Klunder, M.B., Laan, P., Middag, R., de Baar, H.J.W., van Ooijen, J.C., 2011. Dissolved iron in the Southern Ocean (Atlantic Sector). Deep-Sea Research II 58. 2678-2694.

Landing, W.M., Bruland, K.W. 1980. Manganese in the North Pacific. Earth and Planetary Science Letters 49. 45-56.

Landing, W.M., Bruland, K.W., 1987. The contrasting biogeochemistry of iron and manganese in the Pacific Ocean. Geochim. Cosmochim. Acta 51, 29-43.

LeBel, D.A., Smethie Jr., W.M., Rhein, M., Kieke, D., Fine, R.A., Bullister, J.L., Min, DH., Roether, W., Weiss, R.F., Andrie, C., Smythe-Wright, D., Jones, E.P. 2008. The formation rate of North Atlantic Deep Water and Eighteen Degree Water calculated from CFC-11 inventories observed during WOCE. Deep-Sea Research I. 891-910.

Mahowald, N. M., A. R. Baker, G. Bergametti, N. Brooks, R. A. Duce, T. D. Jickells, N. Kubilay, J. M. Prospero, and I. Tegen (2005), Atmospheric global dust cycle and iron inputs to the ocean, Global Biogeochem. Cycles, 19, GB4025, doi:10.1029/2004GB002402.

Martin, J.H., Knauer, G.A. 1984. VERTEX: manganese transport through oxygen minima. Earth and Planetary Science Letters 67. 35-47.

Martin, J.H., Knauer, G.A., Karl, D.M., Broenkow, W.W. 1987. VERTEX: carbon cycling in the northeast Pacific. Deep-Sea Research 34. 267-285. 
Martin, J.H., Fitzwater, S.E., 1988. Iron deficiency limits phytoplankton growth in the north-east Pacific subarctic. Nature 331. 341-343.

Martin, J.H., Gordon, R.M., 1988. Northeast Pacific iron distributions in relation to phytoplankton productivity. Deep Sea Res. A. Oceanogr. Res. Papers 35, 177-196.

Martin, J.H., Gordon, R.M., Fitzwater, S., Broenkow, W.W., 1989. VERTEX: Phytoplankton/iron studies in the Gulf of Alaska. Deep Sea Res. A. Oceanogr. Res. Papers 36. 649-680.

Martin, J.H., Fitzwater, S.E., Gordon, R.M. 1990, Iron deficiency limits phytoplankton growth in Antarctic waters, Global Biogeochem. Cycles 4, 5-12.

Martin, J.H., Fitzwater, S.E., Gordon, R.M., Hunter, C.N., Tan- ner, S.J., 1993. Iron, primary production, and carbon-nitrogen flux studies during the JGOFS North Atlantic bloom experiment. Deep-Sea Res. 40, 115- 134.

Measures, C.I., J. Yang, and J.A. Resing, J., 1995. Determination of iron in seawater by flow injection analysis using in-line preconcentration and spectrophotometric detection, Mar. Chem., 50, 3-12.

Measures, C.I., Vink, S., 2000. On the use of dissolved aluminum in surface waters to estimate dust deposition to the ocean. Global Biogeochemical Cycles 14. 317-327.

Measures, C. I., W. M. Landing, M. T. Brown, and C. S. Buck., 2008. High-resolution Al and Fe data from the Atlantic Ocean CLIVAR-CO2 Repeat Hydrography A16N transect: Extensive linkages between atmospheric dust and upper ocean geochemistry, Global Biogeochem. Cycles, 22, GB1005, doi:10.1029/2007GB003042.

Measures, C.I., Hatta, M., Fitzsimmons, J., Morton, P., Dissolved Al in the zonal N Atlantic section of the US GEOTRACES 2010/2011 cruises. In this issue.

Nishioka, J., Obat, H., Tsumune, D., 2013. Evidence of an extensive spared of hydrothermal dissolved iron in the Indian Ocean. Earth and Planetary Science Letters 361. 26-33. 
Ohnemus, D.C. and P.J. Lam. Cycling of Lithogenic Marine Particulates in the US GEOTRACES North Atlantic Zonal Transect. Submitted to Deep-Sea Research II .

Resing, J. A. and M. J. Mottl, Determination of Manganese in seawater using flow injection analysis with on-line preconcentration and spectrophotometric, Analytical Chemistry, 64, 2682-2687, 1992.

Rijkenberg, M.J.A., Steigenberger, S., Powell, C.F., van Haren, H., Patey, M.D., Baker, A.R., Achterberg, E.P., 2012. Fluxes and distribution of dissolved iron in the eastern (sub-) tropical North Atlantic Ocean, Global Biogeochem. Cycles, 26, GB3004, doi:10.1029/2011GB004264.

Rue, E.L., Bruland, K.W., 1995. Complexation of iron (III) by natural organic ligands in the Central North Pacific as determined by a new competitive ligand equibration/adsorptive cathodic stripping voltammetric method. Marine Chemistry 50. 117-138.

Saito, M.A., Noble, A.E., Tagliabue, A., Goepfert, T.J., Lamborg, G.H., Jenkins, W.J. 2013. Slow-spreading submarine ridges in the South Atlantic as a significant oceanic iron source. Nature geoscience. DOI. 10.1038/NGEO1893.

Schlosser, C., Klar, J.K., Wake, B.D., Snow, J.T., Honey, D.J., Woodward, E.M.S., Lohan, M.C., Achterberg, E.P., Moore, C.M. 2014. Seasonal ITCZ migration dynamically controls the location of the (sub)tropical Atlantic biogeochemical divide. Proceedings of the National Academy of Sciences, 111. 1438-1442. doi:10.1073/pnas.1318670111.

Schlitzer, R., Ocean Data View, http://odv.awi.de, 2012

Sedwick, P. N., T. M. Church, A. R. Bowie, C. M. Marsay, S. J. Ussher, K. M. Achilles, P. J. Lethaby, R. J. Johnson, M. M. Sarin, and D. J. McGillicuddy. 2005. Iron in the Sargasso Sea (Bermuda Atlantic Time-series Study region) during summer: Eolian imprint, spatiotemporal variability, and ecological implications, Global Biogeochem. Cycles, 19, GB4006, doi:10.1029/2004GB002445. 
Sedwick, P.N., B. M. Sohst, A. R. Bowie, A zonal picture of the water column distribution of dissolved iron(II) during the U.S. GEOTRACES North Atlantic Transect cruises, in this issue.

Shelley, R.U, Morton, P.L. and Landing, W.M. Elemental composition of North Atlantic Aerosols (US-GEOTRACES), in this issue.

Shen, G.T., Boyle, and E.A. (1988) Thermocline ventilation of anthropogenic lead in the western North Atlantic, J. Geophys. Res. 93:15715-15732

Shiller, A.M., 1997. Manganese in surface waters of the Atlantic Ocean. Geophysical Research Letters, 24 (12), 1495-1498.

Shiller, A.M., 1998. Dissolved gallium in the Atlantic Ocean, Marine Chemistry 61. 8799.

Smethie Jr., W.M., LeBel, D.A., Fine, R.A., Rhein, M., Kieke, D., 2007. Dtrength and Variability of the Deep Limb of the North Atlantic Meridional Overturning Circulation From Chlorofluorocarbon Inventories. Geophysical MonographyAmerican Geophysical Union, 173. 119-130.

Sunda, W.G., Hunstsman, S.A. 1994. Photoreduction of manganese oxides in seawater. Marine Chemistry 46. 133-152.

Sunda, W.G., Huntsman, S.A. 1995. Iron uptake and growth limitation in oceanic and coastal phytoplankton. Marine Chemistry 50. 189-206.

Sunda, W.G., Huntsman, S.A., Harvey, G.R., 1983. Photoreduction of manganese oxides in seawater and its geochemical and biological implications. Nature 301, 234-236.

Tagliabue, A., Bopp, L., Dutay, J-C., Bowie, A.R., Chever, F., Jean-Baptiste, P., Bucciarelli, E., Lannuzel, D., Remeyi, T., Sarthou, G., Aumont, O., Gehlen, M., Jeandel, C. 2010. Hydrothermal contribution to the oceanic dissolved iron inventory. Nature geoscience 3. 252-256. doi: 10.1038/NGE0818. 
Talley, L.D., M.S., McCartney. 1982. Distributions and Circulation of Labrador Sea Water. Journal of Physical Oceanography 12, 1189-1205.

Talley, L. D., G. L. Pickard, W. J. Emery and J. H. Swift, 2011. Descriptive Physical Oceanography: An Introduction (Sixth Edition), Elsevier, Boston, 560 pp.

Toner, B.M., M.A. Marcus, K.J. Edwards, O. Rouxel, and C.R. German. 2012. Measuring the form of iron in hydrothermal plume particles. Oceanography 25(1): 209-212, http://dx.doi.org/10.5670/ oceanog.2012.19.

Toole, J.M., Curry, R.G., Joyce, T.M., McCartney, M., Pena-Molino, B., 2011. Transport of the North Atlantic Deep Western Boundary Current about $39^{\circ} \mathrm{N}, 70^{\circ} \mathrm{W}$ : 20042008. Deep Sea Research II. 1768-1780.

Twining, B.S., Baines, S.B. 2013. The Trace Metal Composition of Marine Phytoplankton. Annu. Rev. Mar. Sci. 5. 191-215.

Ussher, S. J., E. P. Achterberg, C. Powell, A. R. Baker, T. D. Jickells, R. Torres, and P. J. Worsfold (2013), Impact of atmospheric deposition on the contrasting iron biogeochemistry of the North and South Atlantic Ocean, Global Biogeochem. Cycles, 27, 1096-1107, doi:10.1002/gbc.20056.

Wu, J., Boyle, E.A. 1998. Determination of iron in seawater by high-resolution isotope dilution inductively coupled plasma mass spectrometry after $\mathrm{Mg}(\mathrm{OH}) 2$ coprecipitation. Analytica Chimica Acta 367. 183-191.

Wu, J., Roshan, S., Hatta, M., Measures, C.I., Buck, K.N., Dissolved Fe enrichment in the oxygen minimum zone of the eastern tropical North Atlantic Ocean. Deep Sea Research II, this Issue.

Wu, J., Sunda, W., Boyle, E.A., Karl, D.M., 2000. Phosphate Depletion in the Western North Atlantic Ocean. Science. 289. 759-762.

Wu, J., Wells, M.L., Rember, R. 2011. Dissolved iron anomaly in the deep tropicalsubtropical Pacific: Evidence for long-range transport of hydrothermal iron. Geochimica et Cosmochimica Acta 75. 460-468. 


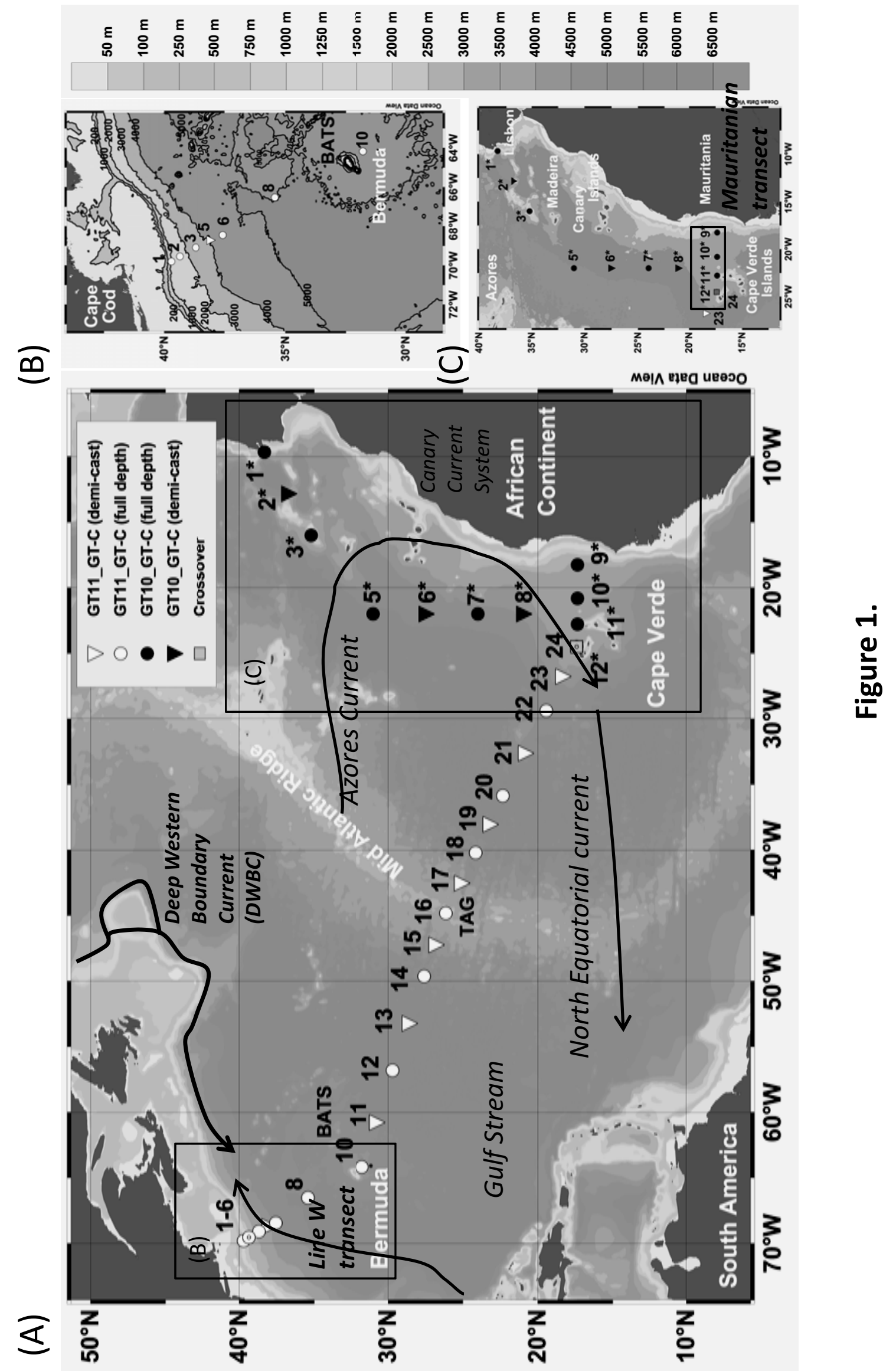




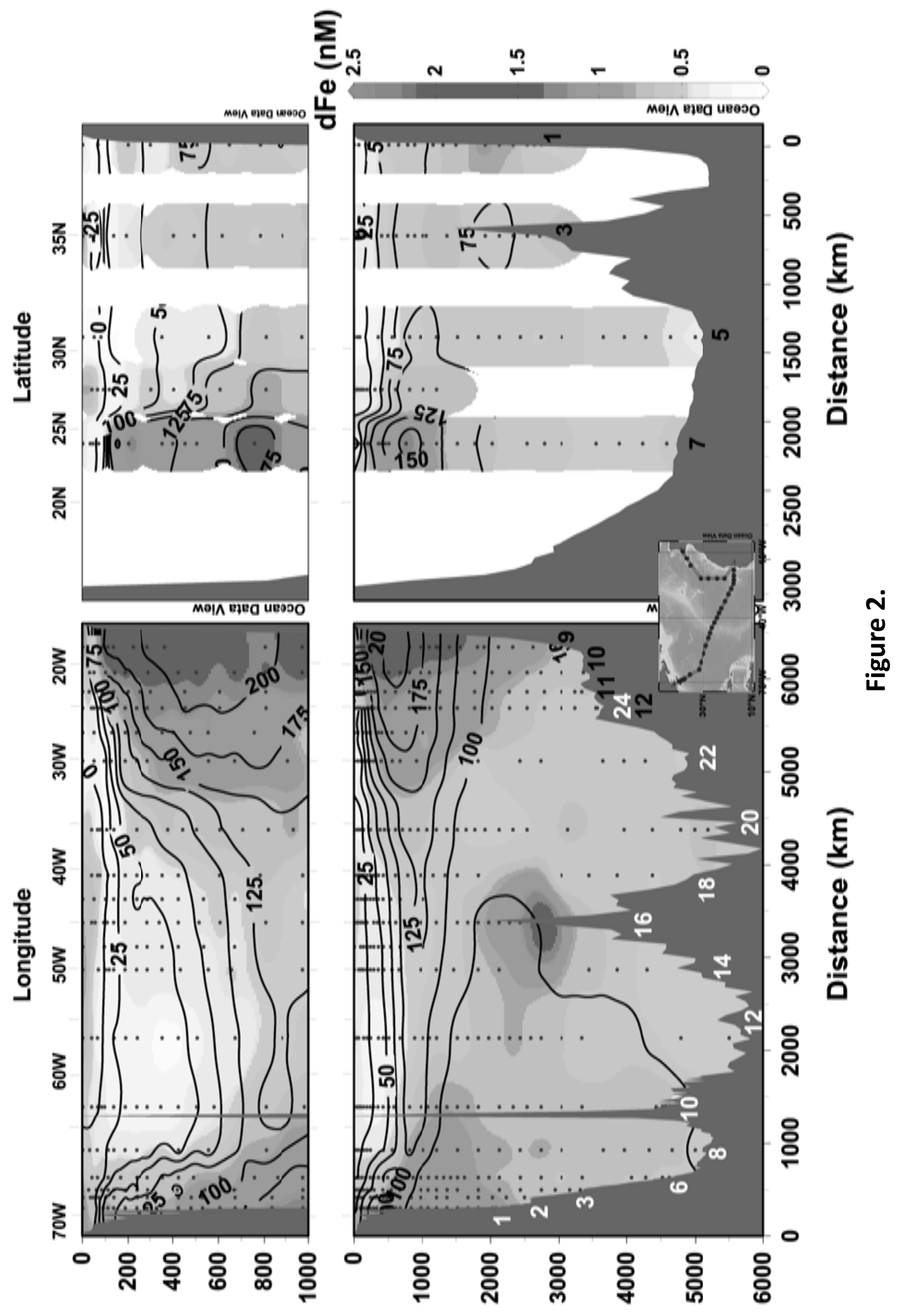




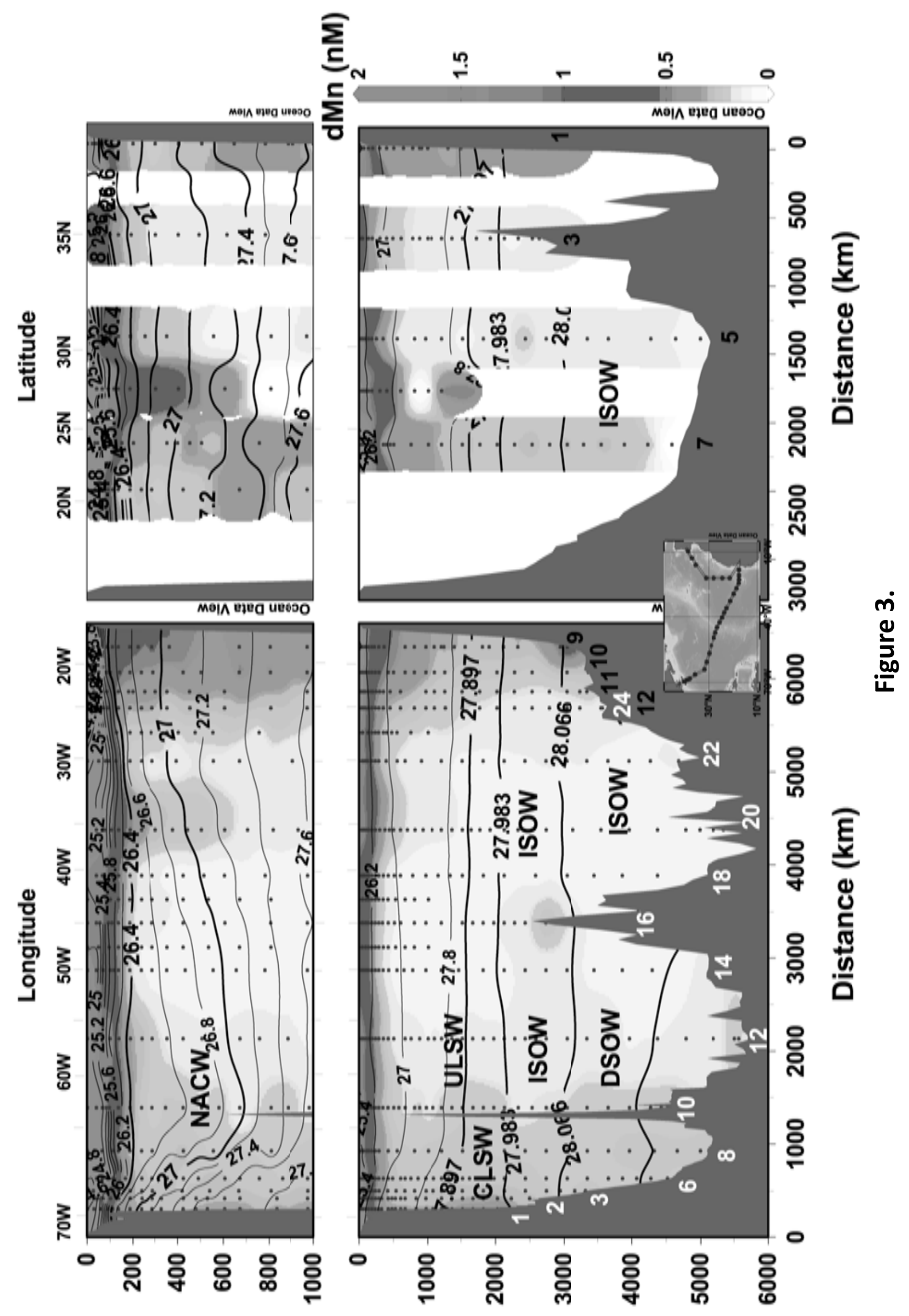



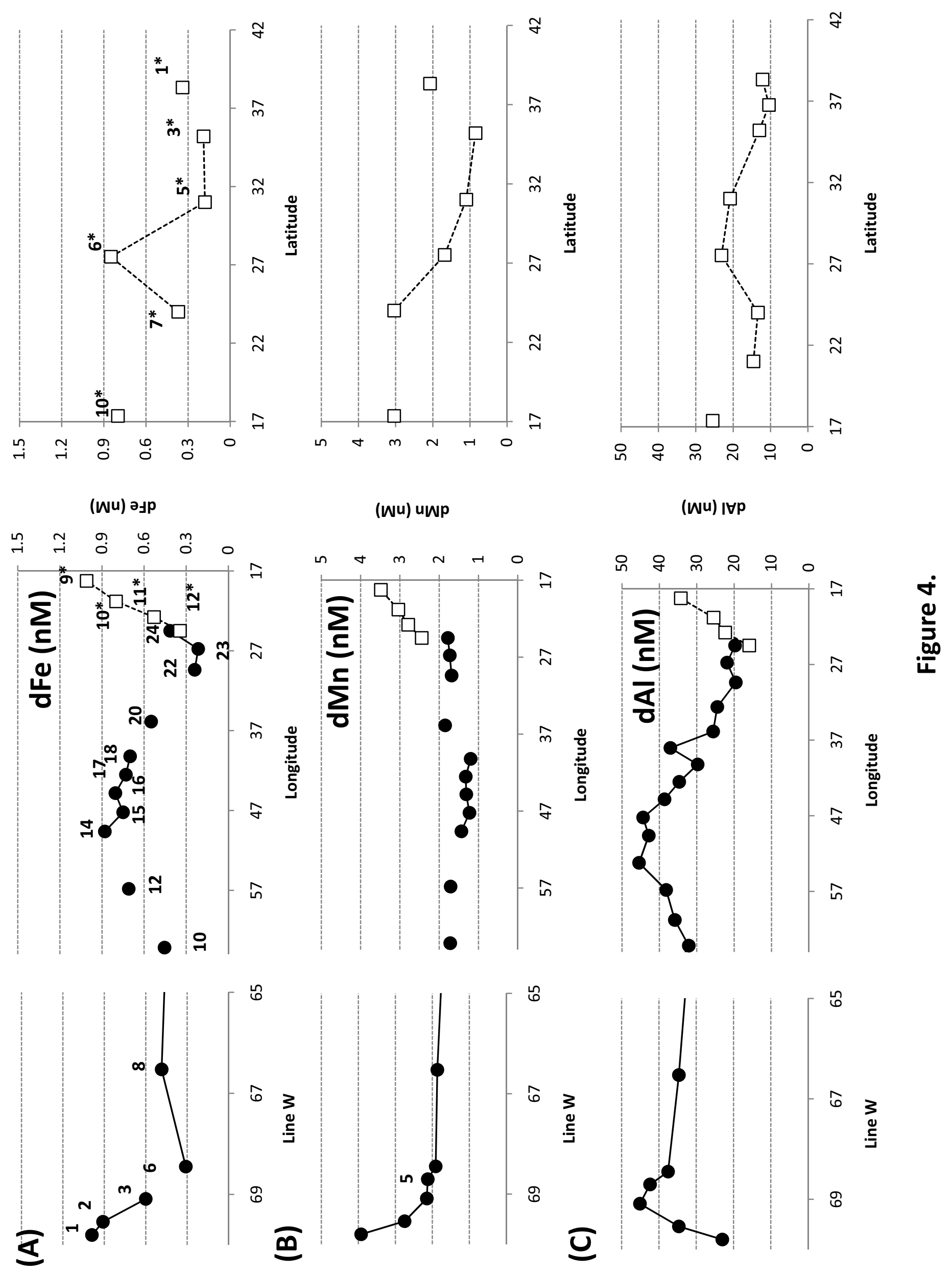


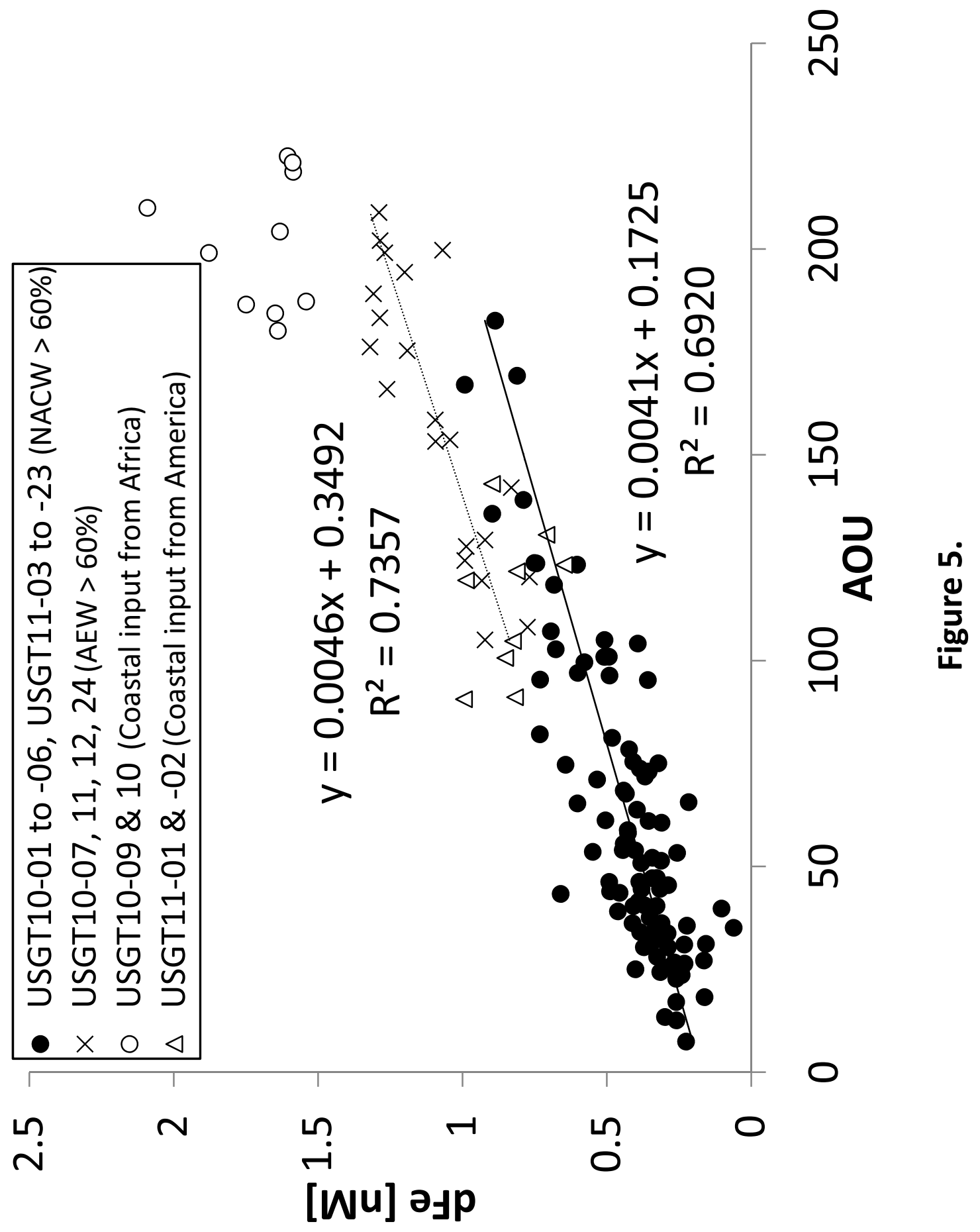




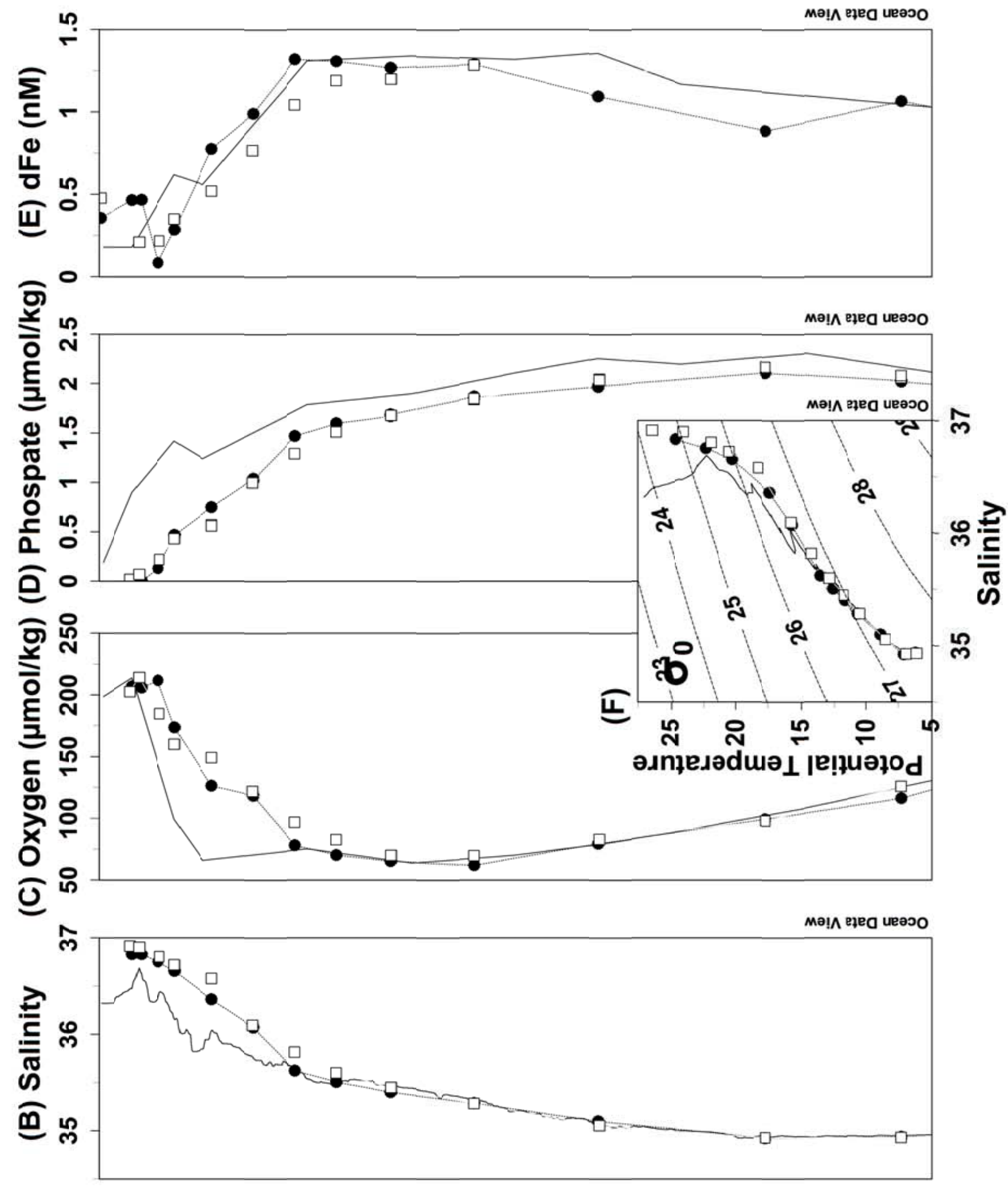

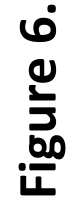

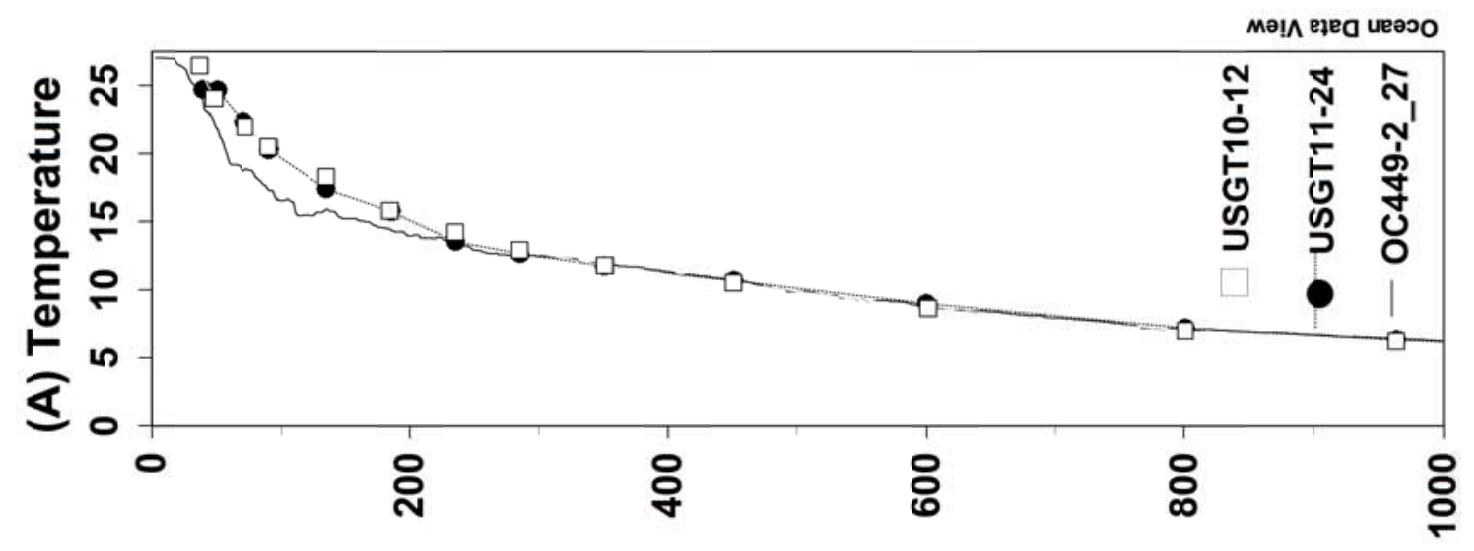



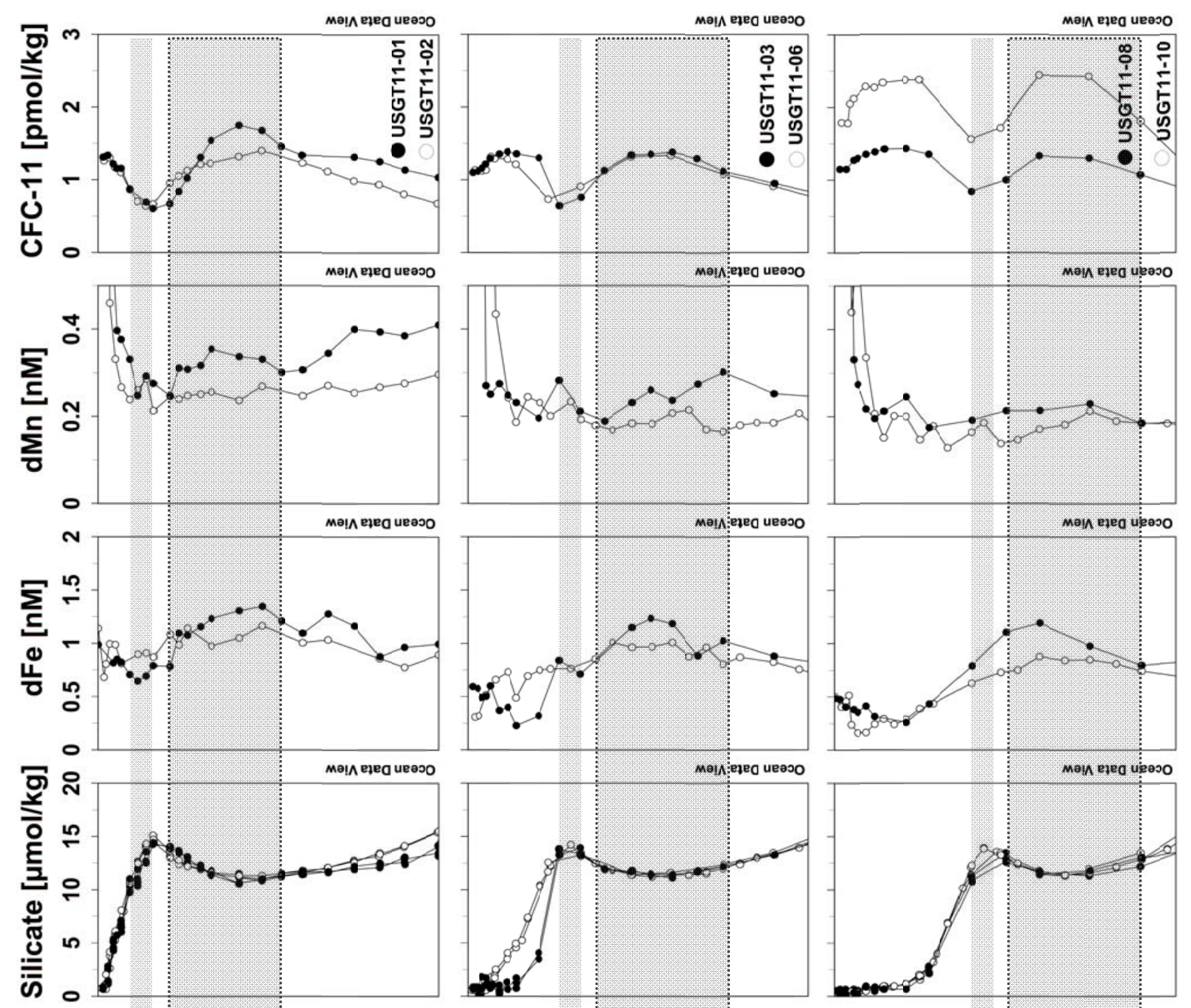

일
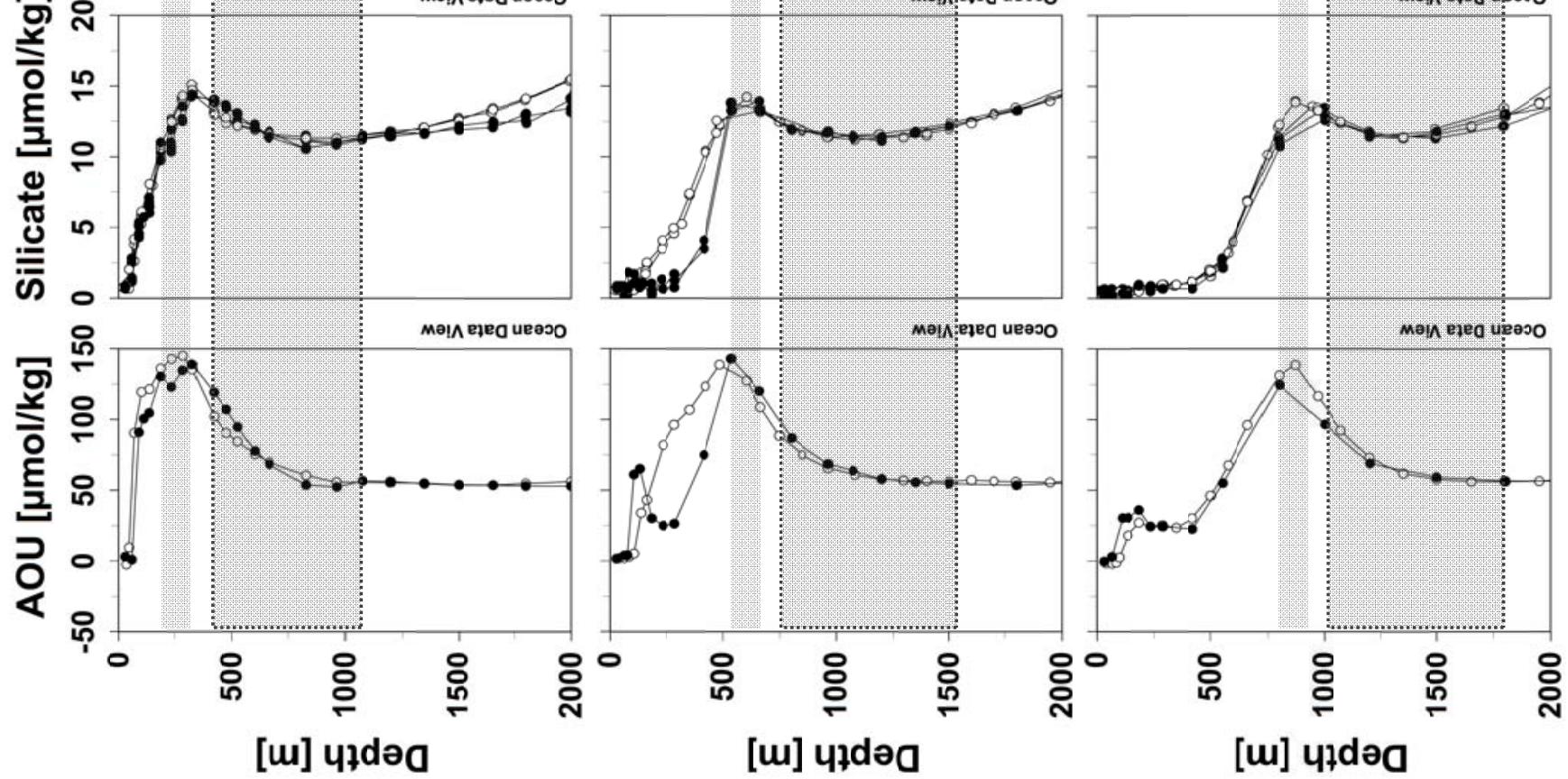

[u] प7dəa 

